\title{
The influence of atmospheric circulation patterns during large snowfall events in New Zealand's Southern Alps
}

\author{
Rasool Porhemmat ${ }^{1 *}$, Heather Purdie ${ }^{1}$, Peyman Zawar-Reza ${ }^{1}$, Christian Zammit ${ }^{2}$, Tim Kerr $^{3}$ \\ ${ }^{1}$ School of Earth and Environment, University of Canterbury \\ *Corresponding author: $\underline{\text { rasool.porhemmat@pg.canterbury.ac.nz }}$ \\ ${ }^{2}$ National Institute of Water and Atmospheric Research, Christchurch, New Zealand \\ ${ }^{3}$ Rainfall.NZ, Christchurch, New Zealand
}

\section{Abstract}

Large snowfall events contribute significantly to total annual snow accumulation across the maritime Southern Alps. However, the knowledge about atmospheric circulation patterns associated with large snowfall events over the New Zealand Southern Alps is very limited. Daily snow observation data from three automatic weather stations and ERA-Interim reanalysis data were used to investigate the relationship between atmospheric forcing and large snowfall events across the Southern Alps. To do so, analysis of composite anomaly maps during large snowfall events were carried out to identify the common features of the days with heavy snow accumulation. Large snowfall across the Southern Alps are mainly associated with strong negative anomalies of sea level pressure (SLP) located over the southwest of New Zealand's South Island. These conditions are concurrent with negative anomalies of geopotential heights at 500 (Z500) located in the centre of low pressure systems. However, over New Zealand, days leading to large snowfall events experience positive anomalies of Z500 showing a relatively warm environment during such events in the maritime Southern Alps. Positive anomalies of low-tropospheric temperatures ( $850 \mathrm{hPa}$ and $1000 \mathrm{hPa}$ ) over the Tasman Sea and across the Southern Alps, strong values of integrated vapour transport (IVT) as well as high frequency of local synoptic patterns associated with troughing regimes ( 78\%) during large snowfall events provide more evidence of the important contribution of warm air flows.

Keywords: snow, synoptic climatology, anomalies, Southern Alps

This article has been accepted for publication and undergone full peer review but has not been through the copyediting, typesetting, pagination and proofreading process which may lead to differences between this version and the Version of Record. Please cite this article as doi: 10.1002/joc.6966

This article is protected by copyright. All rights reserved. 


\section{Introduction}

Winter precipitation in solid form is one of the main components of mountain climatology in alpine catchments. Snow in the mountains is a natural water reservoir providing water for over one billion people across the globe (Barnett, et al., 2005; Mankin et al., 2015). Numerous studies show that a small number of large (extreme) events can dominate the total seasonal snowpack in snowfall-dominated regions, leading to an increase of river flow during the melt season (Serreze et al., 2001; Kumar et al., 2012; Lute and Abatzoglou, 2014). For instance, in the western United States, large snowfall events have been found to account for up to $38 \%$ of annual snowfall water equivalent (Lute and Abatzoglou, 2014). New findings in Antarctica have revealed that the largest $10 \%$ of snowfall events contribute to $40-60 \%$ of annual snow accumulation (Turner et al., 2019). Given the importance of large snowfall events in snow-dominated regions, it is, therefore, necessary to better understand the processes that lead to such events.

Daily snowfall characteristics and their associated conditions such as temperature, humidity and cloudiness are largely controlled by atmospheric circulation (Birkeland and Mock, 1996; Mock, 1996; Bednorz, 2011; Bednorz and Wibig, 2017). Also, in a warming climate, with a shift in precipitation form from snow-dominated to rain-dominated regimes (IPCC, 2013; Berghuijs et al., 2014), a robust understanding of climate controls on snow accumulation in alpine catchments is necessary for quantifying the ramifications of climate change. Exploring the relationship between climatological phenomena such as snowfall events and atmospheric circulation is, therefore, essential for identifying the current climate characteristics of large snowfall events and the potential impacts of climate change in the future.

A number of processes control the formation of snow in the atmosphere. Investigation of the processes at different scales from microscale to large scales has provided valuable insights into the climate forcing controlling snowfall events in different parts of the globe (Esteban et al., 2005; Romolo et al., 2006). Synoptic patterns, which help identify relationships between the larger scale atmospheric circulation and the smaller scale surface environment, have been a popular tool to study the hydrometeorology of mountain catchments (McGinnis, 2000; Yarnal et al., 2001).

This article is protected by copyright. All rights reserved. 
Synoptic scale processes determine climatological and meteorological conditions at local and regional scales (Yarnal, 1993; Romolo et al., 2006; Sturman and Tapper, 2006). The relationship between synoptic scale processes and snowfall events have been well documented in north America (Birkeland and Mock, 1996; Mock and Birkeland, 2000; Romolo et al., 2006), Japan (Tachibana, 1995; Ikeda et al., 2009; Farukh and Yamada, 2014), European Alps (Spreitzhofer, 1999; Scherrer et al., 2004), central Europe (Bednorz, 2009, 2013; Putniković et al., 2016), the Iberian Peninsula (López-Moreno and Vicente-Serrano, 2007; García-Sellés et al., 2010; Merino et al., 2014; Mora et al., 2016), Himalayas (Simon Wang et al., 2015), the Antarctic continent (Gorodetskaya et al., 2014) and Andes (Masiokas et al., 2006; Garreaud, 2009; Viale and Nuñez, 2011; Stehr and Aguayo, 2017). The inter-relationship of pressure and temperature fields is the main controlling factor of synoptic conditions during the snowfall. Most of these studies are based on an environment-to-circulation approach (Yarnal, 1993), where the atmospheric circulation patterns (e.g. pressure and temperature fields) controlling snowfall events are investigated (Esteban et al., 2005; Romoloet al., 2006). A popular tool to relate the surface environment and atmospheric circulation is the use of composite anomaly maps. The application of composite anomaly maps to investigate atmospheric trends and conditions during snowstorms is reasonably well documented. For example, in Bridger Bowl, located in Montana, United States, Birkeland and Mock (1996) used anomaly maps of $500 \mathrm{hPa}$ heights to study the synoptic patterns associated with abnormal heavy snowfall events (daily snowfall events more than $32.8 \mathrm{~cm}$ ). Analysis of composite anomaly maps of sea level pressure and temperature has been used to examine the circulation pattern leading to large snowfall events (e.g. Esteban et al., 2005; Bednorz, 2011; Farukh and Yamada, 2014; Bednorz and Wibig, 2017).

The large glacier and snowfields of the New Zealand Southern Alps are significant in the middle latitudes of the Southern Hemisphere, second only to South America (Fitzharris et al., 1999). Estimations have shown that seasonal snow usually covers approximately $35 \%$ of the South Island in early spring (Fitzharris et al., 1999; Clark et al., 2009). The alpine rivers in the Southern Alps provide inflows to South Island's largest lakes, many of which are utilised for power generation (Thompson, 2002). They also provide water for irrigation, especially during drought periods (Kerr, 2013; Sirguey, 2009). The proximity of the Southern Alps to the oceans results in maritime conditions where winters are generally mild, so any increase in 
temperature due to climate change would impact the amount of water stored in the seasonal snowpack ( Hendrikx et al., 2012; Hendrikx et al., 2013; Jobst et al., 2018; Jobst, 2016; Poyck et al., 2011). Despite the essential role of seasonal snow as an important water reservoir in the region, less attention has been paid to atmospheric controls of seasonal snow accumulation. Synoptic climatology has been found to influence the hydrometeorology of the Southern Alps (Neale and Fitzharris, 1997; Purdie et al., 2011; Webster et al., 2015; Little et al., 2019). It is known that the north-westerly circulation is a key contributor for providing moisture and intense precipitation over the Southern Alps (Kingston \& McMecking, 2015; Kingston et al., 2016; Little et al., 2019; Purdie et al., 2011; Salinger \& Mullan, 1999). Studies on snow accumulation over glaciers on both west and east side of the Southern Alps (Franz Josef, Tasman and Brewster glaciers) highlighted the important role of local synoptic patterns during the snowfall events (Purdie et al., 2011; Cullen et al., 2019; Little et al., 2019). The local synoptic types in New Zealand known as Kidson types (Kidson, 1994, 2000; Renwick, 2011), have been used to describe the synoptic-scale atmospheric patterns associated with snow accumulation over glaciers. Findings of these studies show that the majority of winter snowfall events coincide with troughing regimes (Purdie et al., 2011; Cullen et al., 2019). Despite short-term observations, these site-specific studies have provided basic knowledge about general weather patterns of snowfall accumulation in the Southern Alps. Further information about characteristics of atmospheric circulation prior and during large snowfall events would provide additional insights into the climatology of large snowfall events in the region.

The main objective of this research is to provide further knowledge of large scale circulation that defines atmospheric conditions associated with large snowfall events in a maritime mountain range. Snow observations from three automatic weather stations (AWS) across the Southern Alps (Mahanga, Mueller Hut and Mount Larkins) were used to identify large snowfall events (Figure 1). To analyse the synoptic conditions leading to these large events, anomaly maps of sea level pressure (SLP), geopotential height at $500 \mathrm{hPa}(\mathrm{Z} 500)$, and temperatures at 500, 850 and $1000 \mathrm{hPa}$ (T500, T850 and T1000) are examined prior and during the snowfall days. In order to find the dominant weather types associated with large snowfall events across the Southern Alps analysis of relationships between the events and the frequency of local synoptic patterns (Kidson, 2000) will be conducted. 


\section{Data and Methodology}

\subsection{Study Site}

The South Island of New Zealand spans latitudes $41^{\circ} \mathrm{S}$ to $47^{\circ} \mathrm{S}$ and is dominated by the Southern Alps (Figure 1). The Southern Alps/Kā Tiritiri o te Moana are the highest mountain range in Australasia with the highest peak being Mount Cook/Aoraki (3724 m). With 26 mountain peaks over $3000 \mathrm{~m}$ in elevation, the Southern Alps extend along much of the length of New Zealand's South Island/Te Wai Pounamu, from Nelson to Milford Sound. The circumpolar westerly flow is the dominant feature of the Southern Hemisphere meteorology which significantly influence New Zealand's weather and climate (Sturman and Tapper, 2006; Ummenhofer and England, 2007). Perpendicular to the prevailing westerly air currents, the Southern Alps play an important role in disturbing effects on airflow such as blocking and rerouting of flows and generating eddies and lee troughs (Sturman and Tapper, 2006). The mountains also drive the characteristic synoptic features of the South Island such as orographic precipitation enhancement and weather fronts (Henderson and Thosmson, 1999; Salinger and Mullan, 1999) which impacts the general precipitation patterns of the South Island. Average annual precipitation is highly variable across the South Island ranging from less than $1,000 \mathrm{~mm} /$ year in the eastern parts to over $10,000 \mathrm{~mm} /$ year near the Main Divide (McKerchar et al., 1998; Kerr, 2011).

The main challenge to fully understand the hydrometeorology of snow processes in the mountain catchments of the Southern Alps has stemmed from a lack of systematic snow observations. Unlike the long-term snow observations in the snow-dominated regions the western United States (Serreze et al., 1999), Canada (Mekis et al., 2018) and European Alps (Schöner et al., 2019), snow measurements in the mountain catchments of the Southern Alps are very limited. Improved success in snow measurement however, has been achieved by the establishment of a network of high altitude automatic weather stations (AWS) by the National Institute of Water and Atmospheric Research (NIWA) (Hendrikx \& Harper, 2013). The new network has provided an opportunity to collect climate variables and snow observations close to the Main Divide of the Southern Alps.

This article is protected by copyright. All rights reserved. 
Snow hydrology processes (e.g. snow accumulation and snowmelt) are important hydrological processes in alpine catchments of the Southern Alps. A seasonal snowline of $1000 \mathrm{~m}$ has been reported for different parts of the South Island (Fitzharris et al., 1999). However, because of the maritime characteristics of the Southern Alps, winter rain frequently occurs above 1000 m (Prowse, 1981; Moore and Owens, 1984; Cullen and Conway, 2015). The mean duration of seasonal snow coverage in the Southern Alps is from May to October while the period of snowmelt is very short mainly during November and December (Fitzharris et al., 1999). Compared to the Western United States (Bales et al., 2006; Li et al., 2017; Zheng et al., 2018), European Alps (Penna et al., 2016; Beniston et al., 2018) and Himalayan catchments (Siderius et al., 2013; Bharati et al., 2014; Adnan et al., 2017) where snowmelt is a large fraction of water supplies, the contribution of meltwater to runoff in the Southern Alps catchments is relatively low, but still influences the management of irrigation and hydroelectricity schemes in South Island, New Zealand (McKerchar et al., 1998; Kerr, 2013). Previous estimations have shown that the contribution of seasonal snow to river flows in the upper terrains of the Southern Alps can reach up to $40 \%$ (Sirguey, 2009).

\subsection{Datasets}

Snow and Ice Monitoring Network (SIN)

This study utilises snow depth data recorded at three NIWA AWS sites, namely Mahanga (1955 m a.s.l.), Mueller Hut (1818 m a.s.l.), and Mt Larkins (1900 m a.s.I.) (Figures 1b and 1c). At these stations, snow depth is recorded by ultrasonic sensors (SR50) at hourly resolution alongside climate variables such as air temperature, wind direction and speed, precipitation, humidity, and incoming solar radiation. Data are available since 2009 at Mahanga, 2010 at Mueller Hut and 2014 at Mt Larkins.

The first step in examining the climatology of large snowfall events is to define what constitutes a large event. Many different thresholds have been applied in previous studies. Most of these thresholds are based on climatology and topography of the region of interest. For example, Birkeland and Mock (Birkeland and Mock, 1996) used a daily threshold of $32.8 \mathrm{~cm}$ of snow accumulation in their investigation of the relationship between atmospheric circulation and heavy snowfalls. This threshold characterises the heavy snowfall conditions 
that could lead to hazardous avalanches in the region. An increase in snow accumulation of more than $5 \mathrm{~cm}$ was used in Russian Arctic and Iberian Peninsula to identify large events (Merino et al., 2014; Bednorz and Wibig, 2016). In northern Japan, Farukh and Yamada (2014) selected the topmost 100 snowstorms in order to explore the synoptic climatology related to heavy snowfalls. Bednorz (2013) defined days with more than $20 \mathrm{~cm}$ of daily snow accumulation as extreme events. Hydrological studies often define a large or extreme events such as precipitation, or flooding using percentile-based indices, for example values ranging from $>90^{\text {th }}$ to the $>99.9^{\text {th }}$ percentiles (Coles, 2001; Lute and Abatzoglou, 2014; VicenteSerrano et al., 2017). Because characteristics differ at each of our three sites, a single value threshold cannot be applied. Therefore, daily snowfall events (24-hour snow depth increase) greater than the $90^{\text {th }}$ percentile of at each site was defined as a large snowfall event.

ERA-Interim reanalysis data

Different meteorological fields including sea level pressure (SLP), geopotential height at $500 \mathrm{hPa}$ (Z500) and temperature at 500, 850 and $1000 \mathrm{hPa}$ (T500, T850 and T1000) were retrieved from the European Centre for Medium-Range Weather Forecasts (ECMWF) ERAInterim reanalysis data (Dee et al., 2011) at a $0.5^{\circ} \times 0.5^{\circ}$ resolution. These data were obtained at 6-hourly intervals for the synoptic window of $10^{\circ} \mathrm{S}-60^{\circ} \mathrm{S}$ and $130^{\circ} \mathrm{E}-160^{\circ} \mathrm{W}$ (Figure 1). The vertical pressure gradient has a non-linear distribution in the atmosphere with a rapid decrease in the lower atmosphere. In terms of altitude, $500 \mathrm{hPa}$ is approximately at $5500 \mathrm{~m}$ a.s.l. in the New Zealand region and is therefore located above the highest peaks in the Southern Alps. The $500 \mathrm{hPa}$ geopotential height is a mid-tropospheric field useful for understanding atmospheric dynamics as it is well above the friction-influenced surface fields (Kidson, 1994; Yarnal et al., 2001). The 850 hPa pressure level lies below $2000 \mathrm{~m}$ a.s.l. which is an important pressure level over the Southern Alps for investigating circulation patterns and meteorological patterns for mountain hydrometeorology controlling the formation of snow in the lower troposphere (Sailor and Li, 1999; Mora et al., 2016).

\subsection{Composite anomaly approach}

A composite anomaly approach was conducted in order to identify relationships between atmospheric circulation patterns and snow accumulation. Composite analysis is commonly 
used to identify the basic structure and characteristics of climatological phenomena as well as exploring the impacts of large scale atmospheric patterns on weather and climate events. This approach explains the differences between averaged values of a selected atmospheric variable and climatic normals. Here anomalies are calculated based on 1979-2018 average values of T500, T850, Z500 and SLP for the main snow accumulation months of June to October (Figure 2). Given the rapid global warming trends during the past decade reported from many snow-dominated regions (Cullen et al., 2019; Hock et al., 2019) the 40-year average is more representative of the climatic normal since it considers the four consecutive ten-year periods instead of the more common 1971-2010 climate averages used in previous studies. In addition, the variability of climate elements has been found to be strongly influenced by inter-decadal processes such as Inter-decadal Pacific Oscillation (IPO) and El-Niño Southern Oscillation (ENSO) over the South Pacific Ocean (Salinger and Jones, 1996; Salinger et al., 2001). Therefore, it is important to use multi-decadal climatic averages instead of short-term averages in order to provide a more accurate baseline as climatic normal.

Anomaly maps of T500, T850, Z500 and SLP were computed as the difference between the average value of these variables during the snowfall events and the 40-year average of typical snow accumulation months at high altitudes of the Southern Alps (June to October). Additionally, difference maps of the above mentioned values for the day prior to the snowfall events were constructed by subtracting the values of the day before from the snowfall days. These maps can describe the atmospheric conditions conducive to heavy snow accumulation and help identify the short-lived patterns (less than 24 hours) at mid- and low-troposphere. (Birkeland and Mock, 1996; Sturman and Tapper, 2006). Most of the moisture in the midlatitudes is carried by fast flowing extratropical cyclones and jet streams (Ralph et al., 2004; Neiman et al., 2008; Rutz et al., 2014); therefore, the pace of these changes in flow regimes can be drawn by looking at a one-day difference map of climate conditions during the day prior to the snowstorms.

\subsection{Local synoptic patterns}

Synoptic classification is a useful tool to identify the characteristics of climatic variables (Barry and Perry, 1973; Smithson, 1986; Harman and Winkler, 1991; Yarnal, 1993; Yarnal et 
al., 2001). The analysis of atmospheric circulation over New Zealand (Trenberth, 1976; Sturman et al., 1984; Trenberth and Mo, 1985; Kidson, 1994, 2000) provided information about large scale synoptic patterns and indicated the inter-annual and sub-annual variations. An early study investigated the atmospheric circulation patterns over the South Island of New Zealand and grouped the daily surface synoptic charts from 1961 to 1980 (Sturman et al., 1984). The results indicated the dominance of anticyclonic circulation and westerly flows with anticyclonic south-westerly being the most frequent in all seasons. Kidson $(1994,2000)$ developed a set of daily weather types for New Zealand using 40 years of NCEP/NCAR analysis data (National Centre for Environmental Prediction/National Centre for Atmospheric Research). The twice-daily fields of $1000 \mathrm{hPa}$ geopotential height were used to define twelve synoptic types. These types have been grouped into three regimes, namely troughing, zonal and blocking (Figure 3). Troughing regimes, which are frequent troughs and frontal systems, consist of four synoptic types designated T, SW, TNW and TSW. These generally bring wetter, colder and cloudier conditions to the entire country. They are less frequent in autumn, and are linked to below-normal temperatures in the south and above-normal precipitation over the entire country.

Zonal regimes $(\mathrm{H}, \mathrm{HNW}$ and $\mathrm{W})$ represent the dominant west-east wind flows over New Zealand and are typically associated with below-normal precipitation in the north and east of the country. However, they can bring milder conditions in the South Island and potentially lead to precipitation due to westerly flow and showers resulted from HNW and W types. Blocking patterns with highs are more frequent in summer and autumn, stalling or slowing the passage of approaching weather systems. The blocking regimes (HSE, HE, NE, HW and R) are linked to a southwest-northeast contrast in precipitation and above normal temperatures, except on the east coast of both north and south islands. The blocking group are often associated with anomalous northerly flow across much of the country. However, NE and R classes could lead to precipitation in the northern and eastern parts of the North Island. Kidson types have been widely used by researchers to investigate the synoptic climatology of different hydrometeorological phenomena in New Zealand (Smart and McKerchar, 2010; Griffiths, 2011; Renwick, 2011; Parsons et al., 2014). Here, we examine the frequency of the Kidson synoptic types during the large snowfall events over the Southern Alps.

This article is protected by copyright. All rights reserved. 


\section{Results and Discussion}

\subsection{Snowfall events}

Snow cover is spatially and temporally variable across the Southern Alps due to latitude difference, topographic characteristics, proximity to the Main Divide and exposure to wind (Kerr et al., 2013; Webster et al., 2015). Measurements of snow depth at three locations indicate that snowfall events can occur throughout the year (Figure 4). However, the annual variability of snow depth during the study period shows that at Mueller Hut and Mt Larkins snow mainly accumulates from June to October, peaking between mid-September to October (Figures $4 \mathrm{a}$ and $4 \mathrm{~b}$ ). At the most northern station (Mahanga), the snow accumulation season is shorter, ending in September. In the case of seasonal snowpacks, snowmelt occurs over a relatively short period in the Southern Alps. At Mueller Hut and Mt Larkins the snowmelt period is usually between mid-October and mid-December, while at Mahanaga snow depth reduces from approximately late September to mid-November. The total annual snow accumulation at Mueller Hut site is larger than the other two sites. This is likely due to the location of the site (near the Main Divide of the Southern Alps) which is strongly influenced by the spillover effect on the lee side of the Southern Alps during the prevailing westerly and north-westerly precipitation patterns (Neale and Fitzharris, 1997). The spatially variable snow accumulation may also be a result of station location with respect to local topography such as elevation and wind exposure that could lead to a strong inter-annual variation of snow depth in different parts of the Southern Alps (Clark et al., 2011; Kerr et al., 2013; Webster et al., 2015).

Applying the $90^{\text {th }}$ percentile of daily snow depth to identify the large snow fall events led to selecting a threshold of $12.5 \mathrm{~cm}$ of daily snow for Mahanga, $18 \mathrm{~cm}$ for Mt Larkins and $31 \mathrm{~cm}$ for Mueller Hut (Table 1). During the study period, there were 23 large snowfall events (days) at Mahanga, 18 at Mueller Hut and 17 at Mt Larkins. Because large snowfall events were selected based on a daily increase in snow depth, they could also be part of a storm that lasted for more than 24 hours. Also, some of these events occurred across the Southern Alps but resulted in different magnitudes of total 24-hour accumulated snow across the locations. For example, during the $13-15^{\text {th }}$ snowfall event, even though Mueller Hut and Mt Larkins received 
considerable snow throughout the snowstorm, the snowfall events at Mahanga was not categorised as a large snowfall event (greater than $12.5 \mathrm{~cm}$ ). Therefore, in order to identify the weather patterns associated with large events at individual locations, our analysis is limited to days with snowfall events greater than the threshold at each location. These large events can play a vital role in the hydrology of the Southern Alps by contributing to a sizeable fraction of the total snow accumulation. Up to $35-40 \%$ of annual snow accumulation recorded at Mueller Hut (2016/17) was received during these large events. July recorded the highest number of large snowfall events (14 days), while August and September ranked equally with 10 snowfall events (Figure 5). Large snowfall events were also frequent during spring (6 events in October and 7 events in November) demonstrating the importance of late season snowfall to annual snow accumulation totals.

\subsection{Atmospheric anomalies during large snowfall events}

The analysis of composite anomaly maps found that large snowfall events are always associated with distinctive negative anomalies of SLP in the Southern Alps (Figure 6a). The negative anomalies are centred over the Tasman Sea to the south west of New Zealand (near $46-48^{\circ} \mathrm{S}$ and $\left.160-165^{\circ} \mathrm{E}\right)$. Even though the overall patterns of SLP anomalies are similar during the large snowfall days, stronger anomalies were evident at Mueller Hut and Mt Larkins. The SLP at the centre of the lows during events at Mahanga, Mueller Hut and Mt Larkisn decreased by $12.3 \mathrm{hPa}, 15.5 \mathrm{hPa}$ and $18.4 \mathrm{hPa}$ relative to long-term winter averages, respectively. These patterns are similar to those identified by Hendrikx (2007) for the historic 12 June 2006 snow storm in Canterbury region where a pressure depression of $24 \mathrm{hPa}$ combined with a very cold front from the southwest lead to an exceptional snow storm with a record snow accumulation in some parts of the Canterbury region. Anomalies of geopotential heights at $500 \mathrm{hPa}(\mathrm{Z500})$ are negative in the vicinity of low centres. Despite existence of negative anomalies of $Z 500$ close to the centre of low pressure systems, the Southern Alps and Tasman Sea experience positive anomalies during major snowfall events (Figure 6b). Geopotential height represents the actual height of a pressure surface above mean sea level. Generally, geopotential heights are lower (higher) in colder (warmer) air masses. This is due to the higher density of cold air which results in lower surface pressure.

This article is protected by copyright. All rights reserved. 
Even though the central anomalies of $Z 500$ are negative, across the Southern Alps anomalies are positive. These patterns differ from that reported in other locations. In northern Japan, Farukh and Yamada (2014) reported negative anomalies of geopotential height at $500 \mathrm{hPa}$ caused by cold air masses originating from eastern Siberia during extreme snowfall episodes. Birkeland and Mock (1996) also noted heavy snowfall events in the Bridger Range of Montana, United states are related to cold north-westerly airflows leading to strong negative anomalies of geopotential height at $500 \mathrm{hPa}$. The positive anomaly of geopotential height can be related to warmer airmass between $1000 \mathrm{hPa}$ and $500 \mathrm{hPa}$ pressure levels at mid and lower troposphere. The average values of 6-hourly integrated vapour transport (IVT) from ERA-Interim (Figure 7) reveals relatively high moisture flux (greater than $250 \mathrm{~kg} \mathrm{~m}^{-1} \mathrm{~s}^{-1}$ ) along the west coast of South Island during large snowfall events. The average IVT is within the range of $260-300 \mathrm{~kg} \mathrm{~m}^{-1} \mathrm{~s}^{-1}$ over the period of the snowstorms (260 kg m $\mathrm{kg}^{-1}$ at Mahanga $290 \mathrm{~kg} \mathrm{~m}^{-1} \mathrm{~s}^{-1}$ at Mueller Hut and $275 \mathrm{~kg} \mathrm{~m}^{-1} \mathrm{~s}^{-1}$ at Mt Larkins).

Anomaly maps of temperature during the snowfall events revealed that it is highly probable that the warmer temperatures occur mostly in the lower troposphere. In the mid troposphere $(500 \mathrm{hPa})$ weak negative anomalies of temperature with values between -1 and $0^{\circ} \mathrm{C}$ are seen (Figure 8a). However, the temperature patterns at $850 \mathrm{hPa}$ show positive anomalies with values between above $0{ }^{\circ} \mathrm{C}$ and $1{ }^{\circ} \mathrm{C}$ over the Southern Alps (Figure 8b). The temperature anomalies at $1000 \mathrm{hPa}$ seems to be slightly stronger at lower pressure levels in the region (at $1000 \mathrm{hPa}$, Figure 8c). These positive anomaly patterns of temperature are evident signs of north-westerly airflows with warmer temperatures at lower troposphere during the occurrence of large snowfall events in the Southern Alps. In the period of 1979-2017 standard deviations of temperature at $850 \mathrm{hPa}$ had a range between $0.89^{\circ} \mathrm{C}$ (October) to $1.46^{\circ} \mathrm{C}$ (December). At $500 \mathrm{hPa}$, standard deviation of temperature changed between $0.98{ }^{\circ} \mathrm{C}$ (October) and $1.43^{\circ} \mathrm{C}$ (November). Therefore, these anomalies are significant considering the variations of temperature at different pressure levels throughout the year.

The positive anomalies of temperature at lower troposphere are somewhat similar to the findings of previous studies in other maritime environments of the eastern Russian Arctic 
and the western United States. Bednorz and Wibig (2016) reported strong positive anomalies of temperature during snowfall events over the eastern Russian Arctic due to the warm cyclonic airflows from Pacific Ocean. Similarly, above-normal temperatures (at 925 $\mathrm{hPa}$ ) related to heavy winter precipitation has been reported over the western United States (latitudes north of $37^{\circ} \mathrm{N}$ ) where the majority of heavy winter precipitation is associated with cyclonic activities and atmospheric rivers in the region (Neiman et al., 2008). Conversely, in continental Europe, strong negative anomalies of temperature have been reported during heavy snowfall episodes due to the impacts of polar continental anticyclones over eastern Europe (Bednorz, 2013). Findings from solid winter precipitation in mid-latitude Chilean and Argentinian Andes $\left(32.5^{\circ}\right.$ and $34^{\circ} \mathrm{S}$ ) found negative temperature anomalies during large snowfall events (Viale and Nuñez, 2011). This cooler than average environment in the Andes is attributed to the influence of cold fronts approaching the west coast of South America and replacing warmer anticyclonic patterns over the region during intense and extreme snowfall events. A comparison between temperature anomalies during large snowfall events in the Southern Alps and South American Andes suggests that despite the different patterns of temperature anomalies (below average temperatures for the Andes and above average temperatures for the Southern Alps) the anomalies at these two mid-latitude maritime environments are not as significant as those in high latitude maritime environments (e.g. Arctic regions). This can be explained by the higher temperature difference between warmer cyclonic systems responsible for winter precipitation and climatic normals at higher latitudes while in mid-latitude maritime regions differences between the weather systems resulting in snowfall events and climatic normals are not significantly distinctive during winter solid precipitation.

To evaluate the rapidly changing atmospheric conditions leading to large snowfall events, the difference fields of atmospheric variables were constructed by subtracting the values of the snowfall day from the values of the day prior to the events. On average SLP drops by 4 to $8 \mathrm{hPa}$ on the day of snowfall compared to the day prior. A depression system extending over the Southern Alps is noticeable during the large snowfall events (Figure 9a). Similarly, the 500 $\mathrm{hPa}$ geopotential patterns indicate a large difference between the days of snowfall and the day prior to snowfall with values up to $75 \mathrm{~m}$ (Figure 9b). This demonstrates a rapid change in 
sea level pressure and geopotential heights across the Tasman Sea and the Southern Alps. Rapid airflows with an eastward direction towards the Southern Alps resembles the rapidly changing conditions reported in the western United States (Birkeland and Mock, 1996) where intensified troughs are developed alongside the west coast and helps develop heavy snowfall events at high altitudes. One-day difference fields of temperature differences at $500 \mathrm{hPa}$ shows colder temperature (Figure 10a). This is an indicator of the colder air masses at upper levels of airflows responsible for moisture transport during the snow events compared to the day prior to the snowfall event. Unlike the conspicuous temperature differences at higher pressure levels there are no distinctive temperature differences at lower levels. The zero line (no difference between the snowfall day and the day before) is located close to the locations of the sites indicating the temperatures during the day of snowfall and the day prior to the event do not vary significantly at 1000 and $850 \mathrm{hPa}$ pressure levels (Figure 10b and Figure 10c).

\subsection{Local synoptic patterns associated with heavy snowfall}

The trough regime accounts for most of the snow accumulation in the Southern Alps. All three sites receive the majority of their snow during troughing synoptic regime, $74 \%$ at Mahanga, 88\% at Mueller Hut and 70.5\% at Mt Larkins (Figure 11 and Table 2). All four Kidson types belonging to the troughing regime contribute to snow accumulation. However, the $T$ type contributes more than any other, with $34 \%, 66 \%$ and $58 \%$ of observed snow accumulation at Mahanga, Mueller Hut and Mt Larkins, respectively.

Zonal group types (W and HNW) account for $15 \%$ of large snowfall events at all sites. Zonal patterns are generally associated with anticyclones in the north, but they can have a different influence in the South Island due to westerly flows and moisture carried by HNW and W types. Mt Larkins (29.5\%) and Mahanga (13\%) received more of their large snowfall events during zonal conditions compared to Mueller Hut (5.5\%). The most important zonal weather type associated with snowfall occurrence is the $\mathrm{W}$ type responsible for 9 large events during the study period. Four snowfall events took place during blocking conditions (HE type) accounting for about $8 \%$ of snowfall events. In the Southern Hemisphere, high pressure systems generally result in warmer than average temperatures across New Zealand. In such systems

This article is protected by copyright. All rights reserved. 
the high pressure builds and persists in place for a prolonged period of time. Even though the HE type generally coincides with high pressure conditions in the north east and anomalous northerly flow across the country (Kidson, 2000; Renwick, 2011) our observations show that the formation of a low system on the west coast over the Tasman Sea could bring about a condition favourable for precipitation over the Southern Alps. The stationary blocking highs slow down the low pressure system moving towards New Zealand and the solid precipitation falls on the edge of the two systems (Figure 12).

Our results support the findings on Franz Josef and Tasman glaciers where approximately $75 \%$ of the winter snowfall was found to coincide with troughing regimes (Purdie et al., 2011). The largest snowfall events at each location occurred during north-westerly troughing regimes (i.e. 23-24 $4^{\text {th }}$ July 2009 event at Mahanga, 13-14 ${ }^{\text {th }}$ July 2016 event at Mueller Hut, and $11-12^{\text {th }}$ October event at Mt Larkins). These synoptic conditions are usually associated with relatively warm weather systems originating from tropics and carrying high moisture flux over the Tasman Sea during winter. Likewise, analysis of snow observations on Brewster Glacier (a mountain glacier on the west side of the Main Divide, Figure 1c) has shown that the largest snowfall events occur during troughing regimes (mainly TNW type) with strong west to north-west airflows (Little et al., 2019). However, recent studies on Brewster Glacier by Cullen et al. (2019) concluded that the W type during zonal conditions are the main contributor to total snow accumulation on Brewster glacier. It is not clear how such synoptic types influence snow accumulation in other parts of the Southern Alps.

\section{Summary and Conclusion}

Here we investigated the importance of large snowfall events to total snow accumulation in the Southern Alps finding that up to $35-40 \%$ of annual snow accumulation was received during the large snowfall events highlighting the important large events make to snow hydrology in alpine catchments. Previously, despite some work using short term data from limited locations across the Southern Alps, the knowledge about annual variability of snowfall across this maritime mountain range was very limited. Observations of snow depth used in this study provided a better understanding of the general patterns of snow accumulation in the region. Based on timing of the occurrence, it was found that large snowfall events are not 
only limited to the typical snow accumulation months of June to September/October as such large events also occur in spring (October and November). Snow observations from three locations across the Southern Alps provided an opportunity to identify the large-scale weather patterns associated with large snowfall events across the Southern Alps. It is evident that general synoptic conditions during large snowfall events contain somewhat similar patterns at three locations in north, middle and south of the Southern Alps. However, due to different characteristics such as proximity to moisture source and the Main Divide of the Southern Alps, latitude difference, and other topographic features they receive different amount of snow during the accumulation season.

With adopting a composite anomaly approach, it was found that low pressure systems with deep centres located in the southwest of New Zealand's South Island are the common features of large snowfall events. A depression of geopotential heights at $500 \mathrm{hPa}$ with centres located at relatively similar locations with the centres of low pressure systems is also evident during snowstorms in the Southern Alps. Despite the existence of negative anomalies of $Z 500$ close to the centre of low pressure systems, the Southern Alps and the Tasman Sea experience positive anomalies during major snowfall events. However, perhaps the most interesting patterns associated with large snowfall events were the temperature anomalies that create a unique condition with different characteristics from other maritime conditions. The location of positive anomalies of temperature and geopotential heights at $500 \mathrm{hPa}$ over New Zealand region during large snowfall events are evidence of the prevailing north-westerly airflows travelling over the South Pacific Ocean over the Tasman Sea with relatively warmer temperatures especially at lower levels where anomalies are stronger. This highlights the important role of the Southern Alps in producing the orographic winter precipitation by cooling down adiabatically the warmer air masses coming from Pacific Ocean when they make landfall over the Southern Alps. This situation can result in conditions with temperature not far from the freezing level across the vast areas of the Southern Alps where the majority of large snowfall events can occur at temperature close to the freezing level. The ERA-Interim reanalysis data have been successfully used to describe the synoptic-scale processes, however, due to limitations related to spatial and temporal resolutions, it is recommended to use the recent ERA-5 reanalysis data, the successor to ERA-Interim, in order 
to further investigate the influence of synoptic-scale processes on regional- and local-scale processes (e.g. the role of rain/snow temperature threshold) controlling large snowfall events in mountain regions.

Additional information on synoptic conditions of snowfall events was achieved by computing difference maps of the day with snowfall compared to the day prior. A typical characteristics of synoptic climatology is the short-lived duration and fast moving weather patterns during most snowstorms where a substantial rapid change in the atmospheric fields occurs in the 24 hours leading to the snowfall events. Analysing local synoptic patterns during snowfall events enable us to gain further knowledge about snow accumulation in the region. Using a longer dataset, our results supports previous findings highlighting the importance of a troughing regime in the Southern Alps's snowstorms. It was found that across the Southern Alps about $78 \%$ of the high snowfall events were related to a troughing regime. Why the majority of snowfall events are associated with trough systems can be explained by the amount of moisture brought by these weather patterns through extratropical cyclones and jet streams. In addition to the fast moving weather types associated with troughing regimes, zonal regimes also contribute to large snowfall events to a lesser extent (16\%). Southern Alps can also receive large snowfall events during blocking regimes located on the east of the New Zealand region. These high pressure systems provide conditions favourable for solid precipitation by slowing down low pressure systems over the Tasman Sea moving towards the Southern Alps and resulting in snowfall on the edge of low pressure and high pressure systems.

These findings revealed general weather patterns which control the timing and magnitude of major large snowfall events in a maritime climate. Providing a baseline for a better understanding of the current knowledge of atmospheric forcing influencing such events, these findings have important implications for investigating the possible future changes in frequencies of synoptic weather patterns in a warming climate. Since synoptic characteristics of weather patterns are more easily accessible compared to local in situ measurements, they can be used to assess possible future changes in large snowfall events in mountain regions which have a number of important implications in long term watershed management. The composite anomaly approach used here provides useful information on how the 
meteorological fields change during snow storms; however, they do not explain categorically the potential moisture sources and moisture transport pathways. This could be further investigated by analysing the position and characteristics of the jet streams responsible for transferring moisture across the South Pacific Ocean over Tasman Sea towards the Southern Alps during large snowfall events. Also, there is currently a gap in knowledge regarding the temperature characteristics of snowfall events in the Southern Alps. In particular, the role of rain/snow temperature threshold during snowfall events is largely unknown. Through the analysis of temperature anomalies this study has shown that large snowfall events can occur at temperatures close to the freezing level. This means that changes in climate related to global warming can have significant impacts on the timing and magnitude of the winter snow accumulation in the upper terrains of alpine catchments in the region. Future work will focus on understanding the temperature characteristics of snowfall events in the maritime Southern Alps.

\section{References}

Adnan M, Nabi G, Kang S, Zhang G, Adnan RM, Anjum MN, Iqbal M, Ali AF. 2017. Snowmelt Runoff Modelling under Projected Climate Change Patterns in the Gilgit River Basin of Northern Pakistan. Polish Journal of Environmental Studies, 26(2): 525-542. https://doi.org/10.15244/pjoes/66719.

Bales RC, Molotch NP, Painter TH, Dettinger MD, Rice R, Dozier J. 2006. Mountain hydrology of the western United States. Water Resources Research, 42(8): 1-13. https://doi.org/10.1029/2005WR004387.

Barnett TP, Adam JC, Lettenmaier DP. 2005. Potential impacts of a warming climate on water availability in snow-dominated regions. Nature, 438(7066): 303-309. https://doi.org/10.1038/nature04141.

Barry RG, Perry AH. 1973. Synoptic climatology; methods and applications. Methuen London.

Bednorz E. 2009. Synoptic conditions for rapid snowmelt in the Polish-German lowlands. Theoretical and Applied Climatology, 97(3-4): 279-286. https://doi.org/10.1007/s00704008-0063-z.

Bednorz E. 2011. Synoptic conditions of the occurrence of snow cover in central European lowlands. International Journal of Climatology, 31(8): 1108-1118. https://doi.org/10.1002/joc.2130.

Bednorz E. 2013. Heavy snow in Polish-German lowlands - Large-scale synoptic reasons and economic impacts. Weather and Climate Extremes. Elsevier, 2: 1-6. 
https://doi.org/10.1016/j.wace.2013.10.007.

Bednorz E, Wibig J. 2016. Spatial distribution and synoptic conditions of snow accumulation in the Russian Arctic. Polar Research, 35(1): 25916.

https://doi.org/10.3402/polar.v35.25916.

Bednorz E, Wibig J. 2017. Circulation patterns governing October snowfalls in southern Siberia. Theoretical and Applied Climatology. Theoretical and Applied Climatology, 128(1-2): 129-139. https://doi.org/10.1007/s00704-015-1696-3.

Beniston M, Farinotti D, Stoffel M, Andreassen LM, Coppola E, Eckert N, Fantini A, Giacona F, Hauck C, Huss M, Huwald H, Lehning M, López-Moreno J-I, Magnusson J, Marty C, Morán-Tejéda E, Morin S, Naaim M, Provenzale A, Rabatel A, Six D, Stötter J, Strasser U, Terzago S, Vincent C. 2018. The European mountain cryosphere: a review of its current state, trends, and future challenges. The Cryosphere, 12(2): 759-794. https://doi.org/10.5194/tc-12-759-2018.

Berghuijs WR, Woods RA, Hrachowitz M. 2014. A precipitation shift from snow towards rain leads to a decrease in streamflow. Nature Climate Change, 4(7): 583-586. https://doi.org/10.1038/nclimate2246.

Bharati L, Gurung P, Jayakody P, Smakhtin V, Bhattarai U. 2014. The Projected Impact of Climate Change on Water Availability and Development in the Koshi Basin, Nepal. Mountain Research and Development, 34(2): 118-130. https://doi.org/10.1659/MRD-JOURNAL-D-1300096.1.

Birkeland KW, Mock CJ. 1996. Atmospheric Circulation Patterns Associated with Heavy Snowfall Events, Bridger Bowl, Montana, U.S.A. Mountain Research and Development, 16(3): 281. https://doi.org/10.2307/3673951.

Clark M, Hreinsson EÖ, Martinez G, Tait A, Slater A, Hendrikx J, Owens I, Gupta H, Schmidt J, Woods R. 2009. Simulations of seasonal snow for the south Island, New Zealand. Journal of Hydrology New Zealand, 48(2): 41-58.

Clark MP, Hendrikx J, Slater AG, Kavetski D, Anderson B, Cullen NJ, Kerr T, Örn Hreinsson E, Woods RA. 2011. Representing spatial variability of snow water equivalent in hydrologic and land-surface models: A review. Water Resources Research, 47(7). https://doi.org/10.1029/2011WR010745.

Coles S. 2001. An Introduction to Statistical Modeling of Extreme Values. Springer London: London.

Cullen NJ, Conway JP. 2015. A 22 month record of surface meteorology and energy balance from the ablation zone of Brewster Glacier, New Zealand. Journal of Glaciology, 61(229): 931-946. https://doi.org/10.3189/2015JoG15J004.

Cullen NJ, Gibson PB, Mölg T, Conway JP, Sirguey P, Kingston DG. 2019. The Influence of Weather Systems in Controlling Mass Balance in the Southern Alps of New Zealand. Journal of Geophysical Research: Atmospheres, 124(8): 4514-4529.

https://doi.org/10.1029/2018JD030052.

This article is protected by copyright. All rights reserved. 
Dee DP, Uppala SM, Simmons AJ, Berrisford P, Poli P, Kobayashi S, Andrae U, Balmaseda MA, Balsamo G, Bauer P, Bechtold P, Beljaars ACM, van de Berg L, Bidlot J, Bormann N, Delsol C, Dragani R, Fuentes M, Geer AJ, Haimberger L, Healy SB, Hersbach H, Hólm E V., Isaksen L, Kållberg P, Köhler M, Matricardi M, McNally AP, Monge-Sanz BM, Morcrette J-J, Park B-K, Peubey C, de Rosnay P, Tavolato C, Thépaut J-N, Vitart F. 2011. The ERA-Interim reanalysis: configuration and performance of the data assimilation system. Quarterly Journal of the Royal Meteorological Society, 137(656): 553-597. https://doi.org/10.1002/qj.828.

Esteban P, Jones PD, Martín-Vide J, Mases M. 2005. Atmospheric circulation patterns related to heavy snowfall days in Andorra, Pyrenees. International Journal of Climatology, 25(3): 319-329. https://doi.org/10.1002/joc.1103.

Farukh MA, Yamada TJ. 2014. Synoptic climatology associated with extreme snowfall events in Sapporo city of northern Japan. Atmospheric Science Letters, 15(4): n/a-n/a. https://doi.org/10.1002/asl2.497.

Fitzharris B, Lawson W, Owens I. 1999. Research on glaciers and snow in New Zealand. Progress in Physical Geography: Earth and Environment, 23(4): 469-500. https://doi.org/10.1177/030913339902300402.

García-Sellés C, Peña JC, Martí G, Oller P, Martínez P. 2010. WeMOI and NAOi influence on major avalanche activity in the Eastern Pyrenees. Cold Regions Science and Technology. Elsevier B.V., 64(2): 137-145. https://doi.org/10.1016/j.coldregions.2010.08.003.

Garreaud RD. 2009. The Andes climate and weather. Advances in Geosciences, 22(1): 311. https://doi.org/10.5194/adgeo-22-3-2009.

Gorodetskaya I V., Tsukernik M, Claes K, Ralph MF, Neff WD, Van Lipzig NPM. 2014. The role of atmospheric rivers in anomalous snow accumulation in East Antarctica. Geophysical Research Letters, 41(17): 6199-6206. https://doi.org/10.1002/2014GL060881.

Griffiths. 2011. Drivers of extreme daily rainfalls in New Zealand. Weather and Climate, 31(2011): 24. https://doi.org/10.2307/26169716.

Harman JR, Winkler JA. 1991. SYNOPTIC CLIMATOLOGY: THEMES, APPLICATIONS, AND PROSPECTS. Physical Geography, 12(3): 220-230.

https://doi.org/10.1080/02723646.1991.10642429.

Henderson RD, Thosmson SM. 1999. Extreme Rainfalls in the Southern Alps of New Zealand. Journal of Hydrology (New Zealand), 38(2): 309-330.

Hendrikx J. 2007. The June 2006 Canterbury snowstorm. Journal of Hydrology (New Zealand), 46(1): 33-49.

Hendrikx J, Harper A. 2013. Development of a National Snow and Ice Monitoring Network for New Zealand. Journal of Hydrology New Zealand, 52(2): 83-95.

Hendrikx J, Hreinsson EÖ, Clark MP, Mullan AB. 2012. The potential impact of climate change on seasonal snow in New Zealand: part I-an analysis using $12 \mathrm{GCMs}$. Theoretical and Applied Climatology, 110(4): 607-618. https://doi.org/10.1007/s00704-012-0711-1.

Hendrikx J, Zammit C, Hreinsson EÖ, Becken S. 2013. A comparative assessment of the 
potential impact of climate change on the ski industry in New Zealand and Australia. Climatic Change, 119(3-4): 965-978. https://doi.org/10.1007/s10584-013-0741-4.

Hock R, Rasul G, Adler C, Cáceres B, Gruber S, Hirabayashi Y, Jackson M, Kääb A, Kang S, Kutuzov S, Milner A, Molau U, Morin S, Orlove B, Steltzer HI. 2019. Chapter 2: High Mountain Areas. IPCC Special Report on the Ocean and Cryosphere in a Changing Climate. IPCC Special Report on the Ocean and Cryosphere in a Changing Climate, 131-202.

Ikeda S, Wakabayashi R, Izumi K, Kawashima K. 2009. Study of snow climate in the Japanese Alps: Comparison to snow climate in North America. Cold Regions Science and Technology. Elsevier B.V., 59(2-3): 119-125.

https://doi.org/10.1016/j.coldregions.2009.09.004.

IPCC. 2013. Long-term Climate Change: Projections, Commitments and Irreversibility Pages 1029 to 1076. In: Intergovernmental Panel on Climate Change (ed) Climate Change 2013 - The Physical Science Basis. Cambridge University Press: Cambridge, 1029-1136.

Jobst AM. 2016. The Potential Impacts of Climate Change on the hydro-climate of the Clutha/Mata-Au catchment. University of Otago. University of Otago.

Jobst AM, Kingston DG, Cullen NJ, Schmid J. 2018. Intercomparison of different uncertainty sources in hydrological climate change projections for an alpine catchment (upper Clutha River, New Zealand). Hydrology and Earth System Sciences, 22(6): 3125-3142. https://doi.org/10.5194/hess-22-3125-2018.

Kerr T. 2011. The precipitation distribution in the Lake Pukaki Catchment. Journal of Hydrology New Zealand, 50(2): 361-382.

Kerr T. 2013. The contribution of snowmelt to the rivers of the South Island, New Zealand. Journal of Hydrology New Zealand, 52(2): 61-82.

Kerr T, Clark M, Hendrikx J, Anderson B. 2013. Snow distribution in a steep mid-latitude alpine catchment. Advances in Water Resources. Elsevier Ltd, 55: 17-24. https://doi.org/10.1016/j.advwatres.2012.12.010.

Kidson JW. 1994. Relationship of new zealand daily and monthly weather patterns to synoptic weather types. International Journal of Climatology, 14(7): 723-737. https://doi.org/10.1002/joc.3370140703.

Kidson JW. 2000. An analysis of New Zealand synoptic types and their use in defining weather regimes. International Journal of Climatology, 20(3): 299-316. https://doi.org/10.1002/(SICI)1097-0088(20000315)20:3<299::AID-JOC474>3.0.CO;2-B.

Kingston DG, Lavers DA, Hannah DM. 2016. Floods in the Southern Alps of New Zealand: the importance of atmospheric rivers. Hydrological Processes, 30(26): 5063-5070. https://doi.org/10.1002/hyp.10982.

Kingston DG, McMecking J. 2015. Precipitation delivery trajectories associated with extreme river flow for the Waitaki River, New Zealand. Proceedings of the International Association of Hydrological Sciences, 369: 19-24. https://doi.org/10.5194/piahs-369-192015.

This article is protected by copyright. All rights reserved. 
Kumar M, Wang R, Link TE. 2012. Effects of more extreme precipitation regimes on maximum seasonal snow water equivalent. Geophysical Research Letters, 39(20): 2012GL052972. https://doi.org/10.1029/2012GL052972.

Li D, Wrzesien ML, Durand M, Adam J, Lettenmaier DP. 2017. How much runoff originates as snow in the western United States, and how will that change in the future? Geophysical Research Letters, 44(12): 6163-6172. https://doi.org/10.1002/2017GL073551.

Little K, Kingston DG, Cullen NJ, Gibson PB. 2019. The Role of Atmospheric Rivers for Extreme Ablation and Snowfall Events in the Southern Alps of New Zealand. Geophysical Research Letters, 46(5): 2761-2771. https://doi.org/10.1029/2018GL081669.

López-Moreno JI, Vicente-Serrano SM. 2007. Atmospheric circulation influence on the interannual variability of snow pack in the Spanish Pyrenees during the second half of the 20th century. Hydrology Research, 38(1): 33-44. https://doi.org/10.2166/nh.2007.030.

Lute AC, Abatzoglou JT. 2014. Role of extreme snowfall events in interannual variability of snowfall accumulation in the western United States. Water Resources Research, 50(4): 2874-2888. https://doi.org/10.1002/2013WR014465.

Mankin JS, Viviroli D, Singh D, Hoekstra AY, Diffenbaugh NS. 2015. The potential for snow to supply human water demand in the present and future. Environmental Research Letters. IOP Publishing, 10(11): 114016. https://doi.org/10.1088/1748-9326/10/11/114016.

Masiokas MH, Villalba R, Luckman BH, Le Quesne C, Aravena JC. 2006. Snowpack Variations in the Central Andes of Argentina and Chile, 1951-2005: Large-Scale Atmospheric Influences and Implications for Water Resources in the Region. Journal of Climate, 19(24): 6334-6352. https://doi.org/10.1175/JCLI3969.1.

McGinnis DL. 2000. Synoptic controls on upper Colorado River basin snowfall. International Journal of Climatology, 20(2): 131-149. https://doi.org/10.1002/(SICI)10970088(200002)20:2<131::AID-JOC465>3.0.CO;2-H.

McKerchar AI, Pearson CP, Fitzharris BB. 1998. Dependency of summer lake inflows and precipitation on spring SOI. Journal of Hydrology, 205(1-2): 66-80. https://doi.org/10.1016/S0022-1694(97)00144-3.

Mekis E, Donaldson N, Reid J, Zucconi A, Hoover J, Li Q, Nitu R, Melo S. 2018. An Overview of Surface-Based Precipitation Observations at Environment and Climate Change Canada. Atmosphere-Ocean, 56(2): 71-95.

https://doi.org/10.1080/07055900.2018.1433627.

Merino A, Fernández S, Hermida L, López L, Sánchez JL, García-Ortega E, Gascón E. 2014. Snowfall in the Northwest Iberian Peninsula: Synoptic Circulation Patterns and Their Influence on Snow Day Trends. The Scientific World Journal, 2014(January): 1-14. https://doi.org/10.1155/2014/480275.

Mock CJ. 1996. Climatic Controls and Spatial Variations of Precipitation in the Western United States. Journal of Climate, 9(5): 1111-1125. https://doi.org/10.1175/15200442(1996)009<1111:CCASVO>2.0.CO;2. 
Mock CJ, Birkeland KW. 2000. Snow avalanche climatology of the western United States mountain ranges. Bulletin of the American Meteorological Society, 81(10): 2367-2392. https://doi.org/10.1175/1520-0477(2000)081<2367:SACOTW>2.3.CO;2.

Moore RD, Owens IF. 1984. Controls on Advective Snowmelt in a Maritime Alpine Basin. Journal of Climate and Applied Meteorology, 23(1): 135-142. https://doi.org/10.1175/15200450(1984)023<0135:COASIA>2.0.CO;2.

Mora JÁN, Martín JR, García MM, de Pablo Davila F, Rivas Soriano L. 2016. Climatological characteristics and synoptic patterns of snowfall episodes in the central Spanish Mediterranean area. International Journal of Climatology, 36(14): 4488-4496. https://doi.org/10.1002/joc.4645.

Neale SM, Fitzharris BB. 1997. Energy balance and synoptic climatology of a melting snowpack in the Southern Alps, New Zealand. International Journal of Climatology, 17(14): 1595-1609. https://doi.org/10.1002/(SICI)1097-0088(19971130)17:14<1595::AIDJOC213>3.0.CO;2-7.

Neiman PJ, Ralph FM, Wick GA, Kuo Y-HH, Wee T-KK, Ma Z, Taylor GH, Dettinger MD. 2008a. Diagnosis of an intense atmospheric river impacting the pacific northwest: Storm summary and offshore vertical structure observed with COSMIC satellite retrievals. Monthly Weather Review, 136(11): 4398-4420. https://doi.org/10.1175/2008MWR2550.1.

Neiman PJ, Ralph FM, Wick GA, Lundquist JD, Dettinger MD. 2008b. Meteorological Characteristics and Overland Precipitation Impacts of Atmospheric Rivers Affecting the West Coast of North America Based on Eight Years of SSM/I Satellite Observations. Journal of Hydrometeorology, 9(1): 22-47. https://doi.org/10.1175/2007JHM855.1.

Parsons S, McDonald AJ, Renwick JA. 2014. The use of synoptic climatology with general circulation model output over New Zealand. International Journal of Climatology, 34(12): 3426-3439. https://doi.org/10.1002/joc.3919.

Penna D, van Meerveld HJ, Zuecco G, Dalla Fontana G, Borga M. 2016. Hydrological response of an Alpine catchment to rainfall and snowmelt events. Journal of Hydrology, 537: 382-397. https://doi.org/10.1016/j.jhydrol.2016.03.040.

Poyck S, Hendrikx J, Mcmillan H, Hreinsson EÖ, Woods R, Poyck S, Hendrikx J, Mcmillan H, Örn E, Woods R. 2011. Combined snow and streamflow modelling to estimate impacts of climate change on water resources in the Clutha River, New Zealand. Journal of Hydrology New Zealand, 50(2): 293-311.

Prowse TD. 1981. THE SNOW ENVIRONMENT OF THE CRAIGIEBURN RANGE. Phd thesis, Department of Geography, University of Canterbury, Christchurch, New Zealand. 386 pp.

Purdie H, Mackintosh A, Lawson W, Anderson B. 2011. Synoptic Influences on Snow Accumulation on Glaciers East and West of a Topographic Divide: Southern Alps, New Zealand. Arctic, Antarctic, and Alpine Research, 43(1): 82-94. https://doi.org/10.1657/19384246-43.1.82.

Putniković S, Tošić I, Đurđević V. 2016. Circulation weather types and their influence on precipitation in Serbia. Meteorology and Atmospheric Physics, 128(5): 649-662.

This article is protected by copyright. All rights reserved. 
https://doi.org/10.1007/s00703-016-0432-6.

Ralph FM, Neiman PJ, Wick GA. 2004. Satellite and CALET Aircraft Observations of Atmospheric Rivers over the Eastern North Pacific Ocean during the Winter of 1997/98. Monthly Weather Review, 132(7): 1721-1745. https://doi.org/10.1175/15200493(2004)132<1721:SACAOO>2.0.CO;2.

Renwick JA. 2011. Kidson's synoptic weather types and surface climate variability over New Zealand. Weather and Climate, 31: 3-23.

Romolo L, Prowse TD, Blair D, Bonsal BR, Marsh P, Martz LW. 2006. The synoptic climate controls on hydrology in the upper reaches of the Peace River Basin. Part II: Snow ablation. Hydrological Processes, 20(19): 4113-4129. https://doi.org/10.1002/hyp.6422.

Rutz JJ, Steenburgh WJ, Ralph FM, James Steenburgh W, Martin Ralph F, Steenburgh WJ, Ralph FM, James Steenburgh W, Martin Ralph F. 2014. Climatological Characteristics of Atmospheric Rivers and Their Inland Penetration over the Western United States. Monthly Weather Review, 142(2): 905-921. https://doi.org/10.1175/MWR-D-13-00168.1.

Sailor DJ, Li X. 1999. A Semiempirical Downscaling Approach for Predicting Regional Temperature Impacts Associated with Climatic Change. Journal of Climate, 12(1): 103-114. https://doi.org/10.1175/1520-0442-12.1.103.

Salinger M, Jones P. 1996. Southern Hemisphere climate: the modern record. Papers and Proceedings of the Royal Society of Tasmania, 130(2): 101-107. https://doi.org/10.26749/rstpp.130.2.101.

Salinger MJ, Mullan AB. 1999. New Zealand climate: temperature and precipitation variations and their links with atmospheric circulation 1930-1994. International Journal of Climatology, 19(10): 1049-1071. https://doi.org/10.1002/(SICI)10970088(199908)19:10<1049::AID-JOC417>3.0.CO;2-Z.

Salinger MJ, Renwick JA, Mullan AB. 2001. Interdecadal Pacific Oscillation and South Pacific climate. International Journal of Climatology, 21(14): 1705-1721. https://doi.org/10.1002/joc.691.

Scherrer SC, Appenzeller C, Laternser M. 2004. Trends in Swiss Alpine snow days: The role of local- and large-scale climate variability. Geophysical Research Letters, 31(13): n/a-n/a. https://doi.org/10.1029/2004GL020255.

Schöner W, Koch R, Matulla C, Marty C, Tilg A-M. 2019. Spatiotemporal patterns of snow depth within the Swiss-Austrian Alps for the past half century (1961 to 2012) and linkages to climate change. International Journal of Climatology, 39(3): 1589-1603. https://doi.org/10.1002/joc.5902.

Serreze MC, Clark MP, Armstrong RL, McGinnis DA, Pulwarty RS. 1999. Characteristics of the western United States snowpack from snowpack telemetry (SNOTEL) data. Water Resources Research, 35(7): 2145-2160. https://doi.org/10.1029/1999WR900090.

Serreze MC, Clark MP, Frei A. 2001. Characteristics of large snowfall events in the montane western United States as examined using snowpack telemetry (SNOTEL) data.

This article is protected by copyright. All rights reserved. 
Water Resources Research, 37(3): 675-688. https://doi.org/10.1029/2000WR900307.

Siderius C, Biemans H, Wiltshire A, Rao S, Franssen WHP, Kumar P, Gosain AK, van Vliet MTH, Collins DN. 2013. Snowmelt contributions to discharge of the Ganges. Science of The Total Environment, 468-469: S93-S101. https://doi.org/10.1016/j.scitotenv.2013.05.084.

Simon Wang S-Y, Gillies RR, Fosu B, Singh PM. 2015. The Deadly Himalayan Snowstorm of October 2014: Synoptic Conditions and Associated Trends. Bulletin of the American Meteorological Society, 96(12): S89-S94. https://doi.org/10.1175/BAMS-D-15-00113.1.

Sirguey P. 2009. Monitoring Snow Cover and Modelling Catchment Discharge With Remote Sensing in the Upper Waitaki Basin, New Zealand. Ph. D. thesis, School of Surveying, University of Otago, Dunedin, New Zealand. 436 pp.

Smart GM, McKerchar AI. 2010. More flood disasters in New Zealand. Journal of Hydrology New Zealand, 49(2): 69-78.

Smithson PA. 1986. Synoptic and dynamic climatology. Progress in Physical Geography: Earth and Environment, 10(1): 100-110. https://doi.org/10.1177/030913338601000106.

Spreitzhofer G. 1999. Spatial, temporal and intensity characteristics of heavy snowfall events over Austria. Theoretical and Applied Climatology, 62(3-4): 209-219. https://doi.org/10.1007/s00704005085.

Stehr A, Aguayo M. 2017. Snow cover dynamics in Andean watersheds of Chile (32.0$39.5^{\circ}$ S) during the years 2000-2016. Hydrology and Earth System Sciences, 21(10): 51115126. https://doi.org/10.5194/hess-21-5111-2017.

Sturman AP, Tapper NJ. 2006. The Weather and Climate of Australia and New Zealand. Oxford University Press: Melbourne VIC Australia.

Sturman, Trewinnard, Gorman. 1984. A STUDY OF ATMOSPHERIC CIRCULATION OVER THE SOUTH ISLAND OF NEW ZEALAND (1961-1980). Weather and Climate, 4(2): 53. https://doi.org/10.2307/44279622.

Tachibana Y. 1995. A Statistical Study of the Snowfall Distribution on the Japan Sea Side of Hokkaido and Its Relation to Synoptic-Scale and Meso-Scale Environments. Journal of the Meteorological Society of Japan. Ser. II, 73(3): 697-715. https://doi.org/10.2151/jmsj1965.73.3_697.

Thompson SM. 2002. River discharge from mountains with frequent rain. Journal of Hydrology New Zealand, 41(2): 125-144.

Trenberth KE. 1976. Fluctuations and trends in indices of the southern hemispheric circulation. Quarterly Journal of the Royal Meteorological Society, 102(431): 65-75. https://doi.org/10.1002/qj.49710243106.

Trenberth KE, Mo KC. 1985. Blocking in the Southern Hemisphere. Monthly Weather Review, 113(1): 3-21. https://doi.org/10.1175/1520-0493(1985)113<0003:BITSH>2.0.CO;2.

Turner J, Phillips T, Thamban M, Rahaman W, Marshall GJ, Wille JD, Favier V, Winton VHL, Thomas E, Wang Z, Broeke M, Hosking JS, Lachlan-Cope T. 2019. The Dominant Role of

This article is protected by copyright. All rights reserved. 
Extreme Precipitation Events in Antarctic Snowfall Variability. Geophysical Research Letters, 46(6): 3502-3511. https://doi.org/10.1029/2018GL081517.

Ummenhofer CC, England MH. 2007. Interannual Extremes in New Zealand Precipitation Linked to Modes of Southern Hemisphere Climate Variability. Journal of Climate, 20(21): 5418-5440. https://doi.org/10.1175/2007JCLI1430.1.

Viale M, Nuñez MN. 2011. Climatology of Winter Orographic Precipitation over the Subtropical Central Andes and Associated Synoptic and Regional Characteristics. Journal of Hydrometeorology, 12(4): 481-507. https://doi.org/10.1175/2010JHM1284.1.

Vicente-Serrano SM, Zabalza-Martínez J, Borràs G, López-Moreno Jl, Pla E, Pascual D, Savé R, Biel C, Funes I, Azorin-Molina C, Sanchez-Lorenzo A, Martín-Hernández N, PeñaGallardo M, Alonso-González E, Tomas-Burguera M, El Kenawy A. 2017. Extreme hydrological events and the influence of reservoirs in a highly regulated river basin of northeastern Spain. Journal of Hydrology: Regional Studies, 12: 13-32. https://doi.org/10.1016/j.ejrh.2017.01.004.

Webster CS, Kingston DG, Kerr T. 2015. Inter-annual variation in the topographic controls on catchment-scale snow distribution in a maritime alpine catchment, New Zealand. Hydrological Processes, 29(6): 1096-1109. https://doi.org/10.1002/hyp.10224.

Yarnal B. 1993. Synoptic climatology in environmental analysis: A primer. Belhaven Press. London, UK.

Yarnal B, Comrie AC, Frakes B, Brown DP. 2001. Developments and prospects in synoptic climatology. International Journal of Climatology, 21(15): 1923-1950. https://doi.org/10.1002/joc.675.

Zheng X, Wang Q, Zhou L, Sun Q, Li Q. 2018. Predictive Contributions of Snowmelt and Rainfall to Streamflow Variations in the Western United States. Advances in Meteorology, 2018: 1-14. https://doi.org/10.1155/2018/3765098.

This article is protected by copyright. All rights reserved. 



(c)



(b)

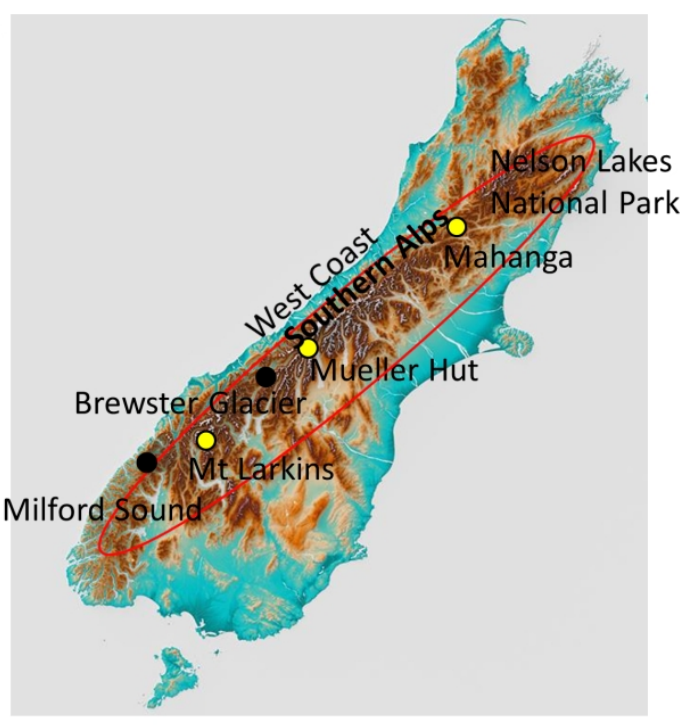

Figure 1. (a) World map and the synoptic window over South Pacific region used in this study (red box: $10^{\circ} \mathrm{S} 60^{\circ} \mathrm{S}$ and $130^{\circ} \mathrm{E} 160^{\circ} \mathrm{W}$ ), (b) locations of automatic snow observation sites in the Southern Alps (yellow dots), and (c) photos of three study sites. Photo credits: NIWA's field team.

$184 \times 189 \mathrm{~mm}(300 \times 300 \mathrm{DPI})$

This article is protected by copyright. All rights reserved. 

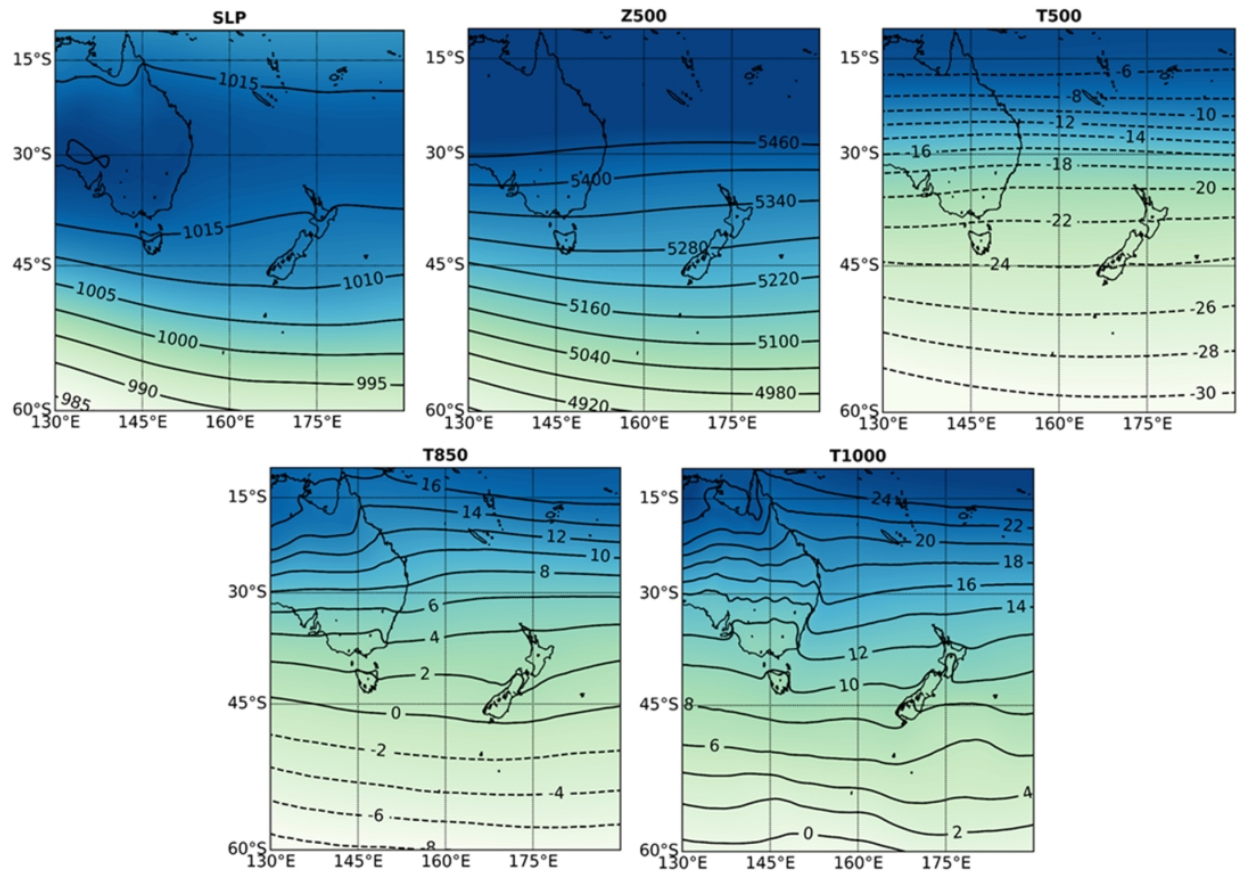

Figure 2. Average SLP ( $\mathrm{hPa}$, contour intervals: $5 \mathrm{hPa}$ ), Z500 (meters, contour intervals: 60 meters), T500 $\left({ }^{\circ} \mathrm{C}\right.$, contour intervals: $\left.2{ }^{\circ} \mathrm{C}\right)$, T850 $\left({ }^{\circ} \mathrm{C}\right.$, contour intervals: $2^{\circ} \mathrm{C}$ ) and T1000 $\left({ }^{\circ} \mathrm{C}\right.$, contour intervals: $2^{\circ} \mathrm{C}$ ) (1979-2018) over New Zealand during the cold months (June, July, August, September and October).

$169 \times 118 \mathrm{~mm}(300 \times 300 \mathrm{DPI})$ 

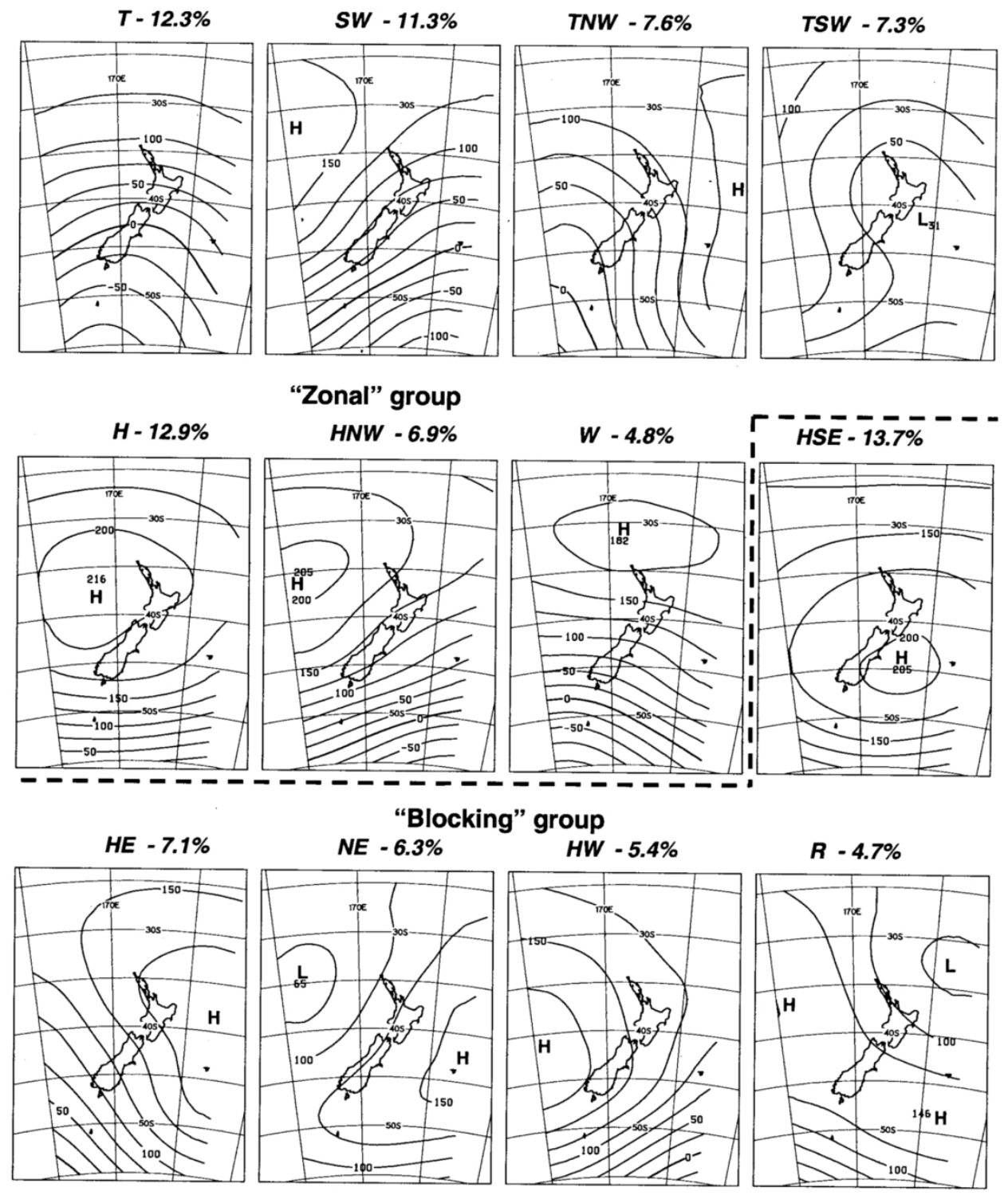

"Blocking" group
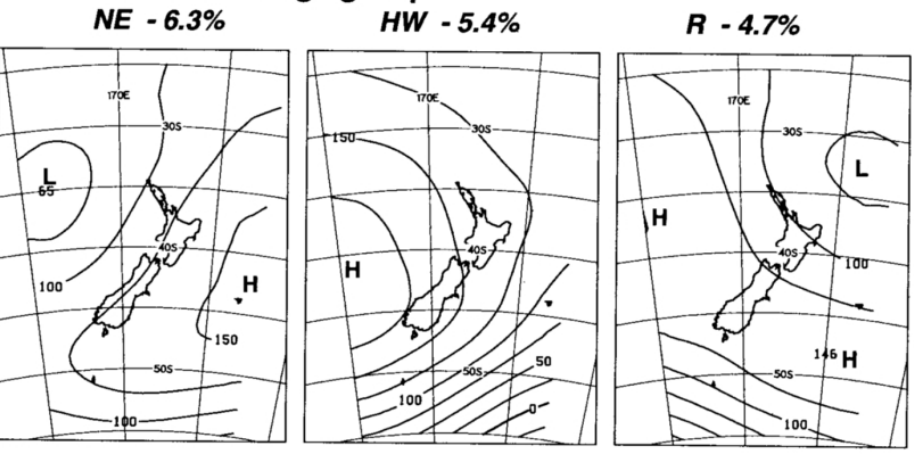

Figure 3. The Kidson Types, Trough (T), South Westerly (SW), Trough North West (TNW), Trough South West (TSW), High (H), High North West (HNW), Westerly (W), High South East (HSE), High East (HE), North Easterly (NE), High West (HW) and Ridge (R). From Kidson (2000). The contours are $1000 \mathrm{hPa}$ geopotential heights (meters).

$166 \times 190 \mathrm{~mm}(300 \times 300$ DPI)

This article is protected by copyright. All rights reserved. 


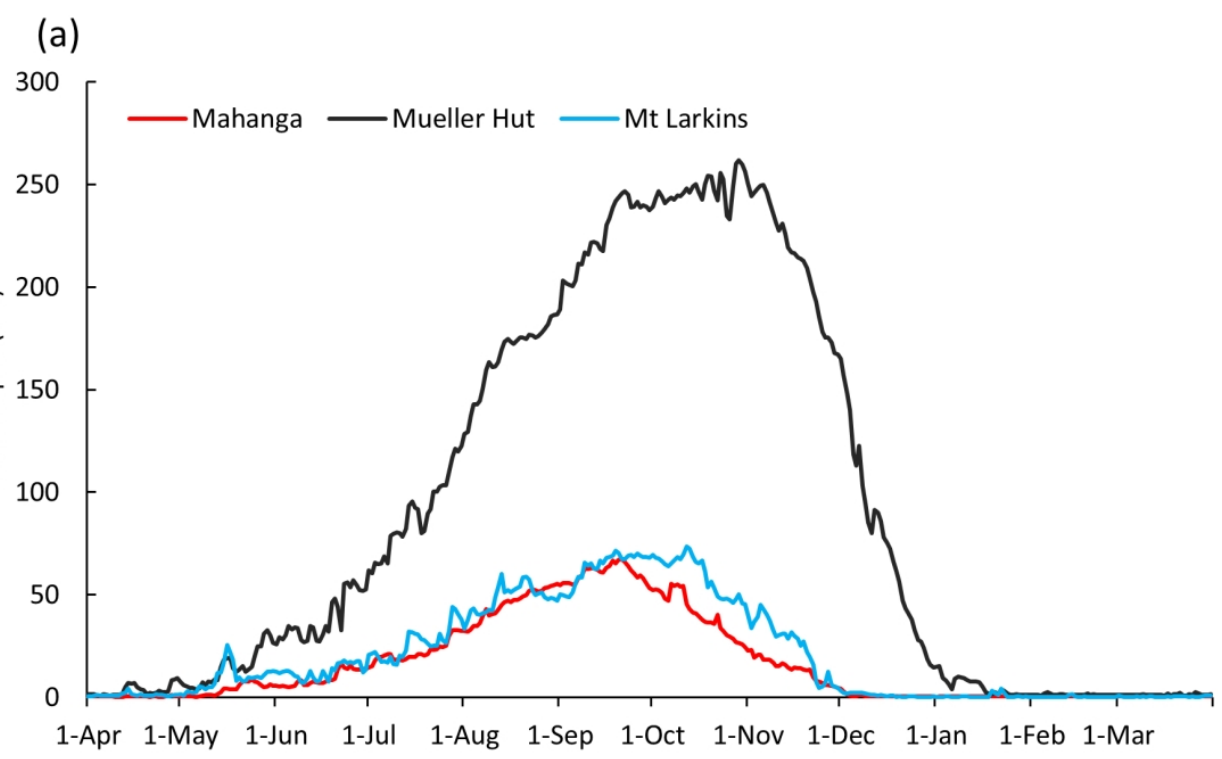

(b)

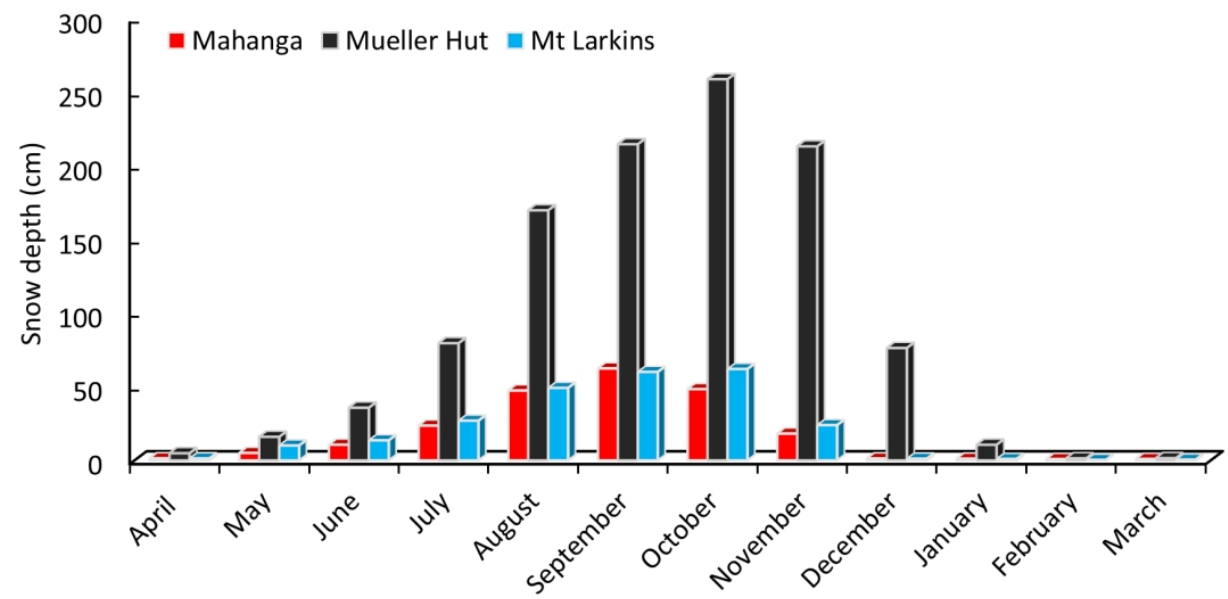

Figure 4. (a) Average daily and (b) average monthly snow depth (cm) measured by SR50 at Mahanga (2010-2018), Mueller Hut (2010-2018) and Mt Larkins (2014-2018).

$$
156 \times 178 \mathrm{~mm}(300 \times 300 \text { DPI) }
$$

This article is protected by copyright. All rights reserved. 


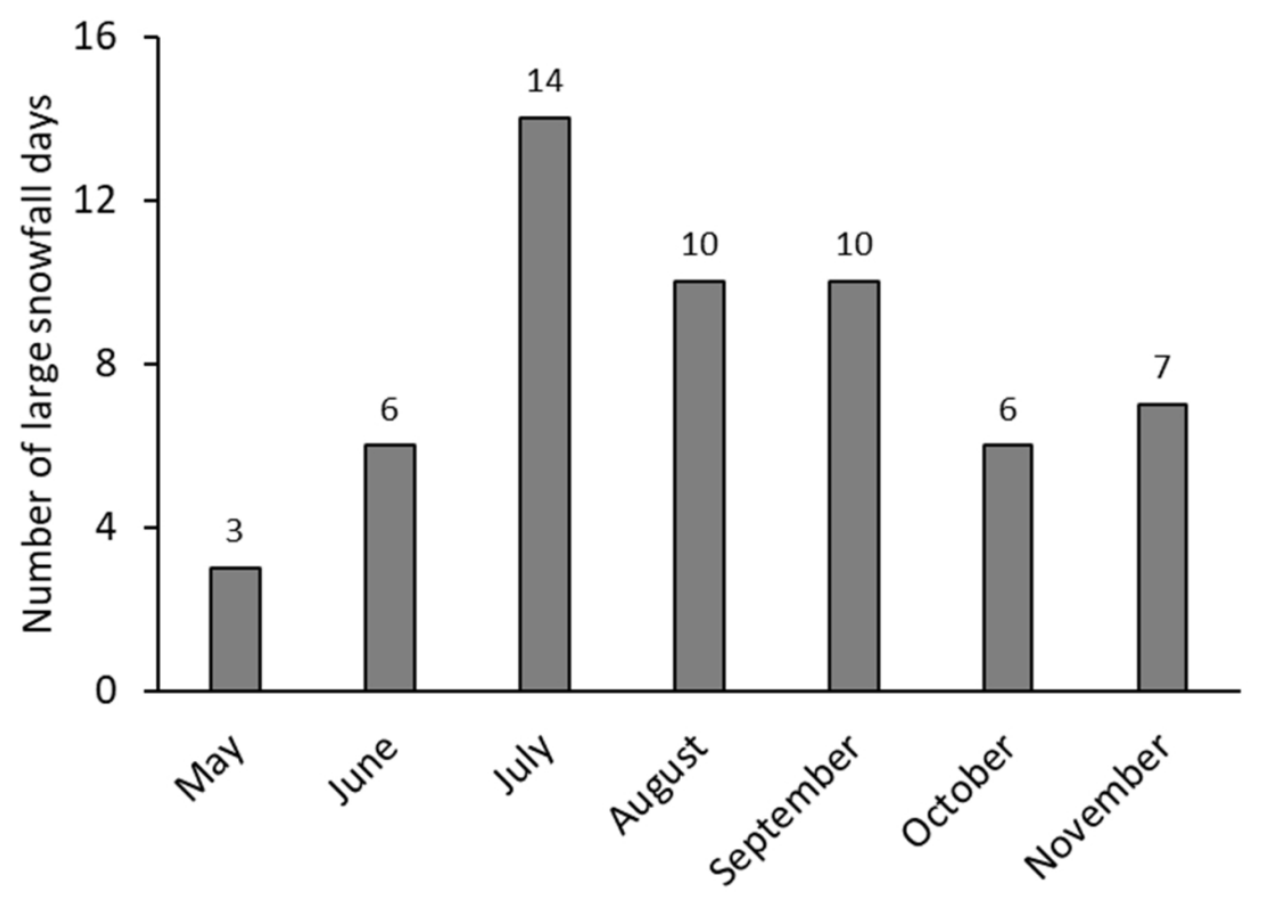

Figure 5. Total number of large snowfall days from June to November at three sites. $118 \times 83 \mathrm{~mm}(300 \times 300 \mathrm{DPI})$

This article is protected by copyright. All rights reserved. 
(a) SLP
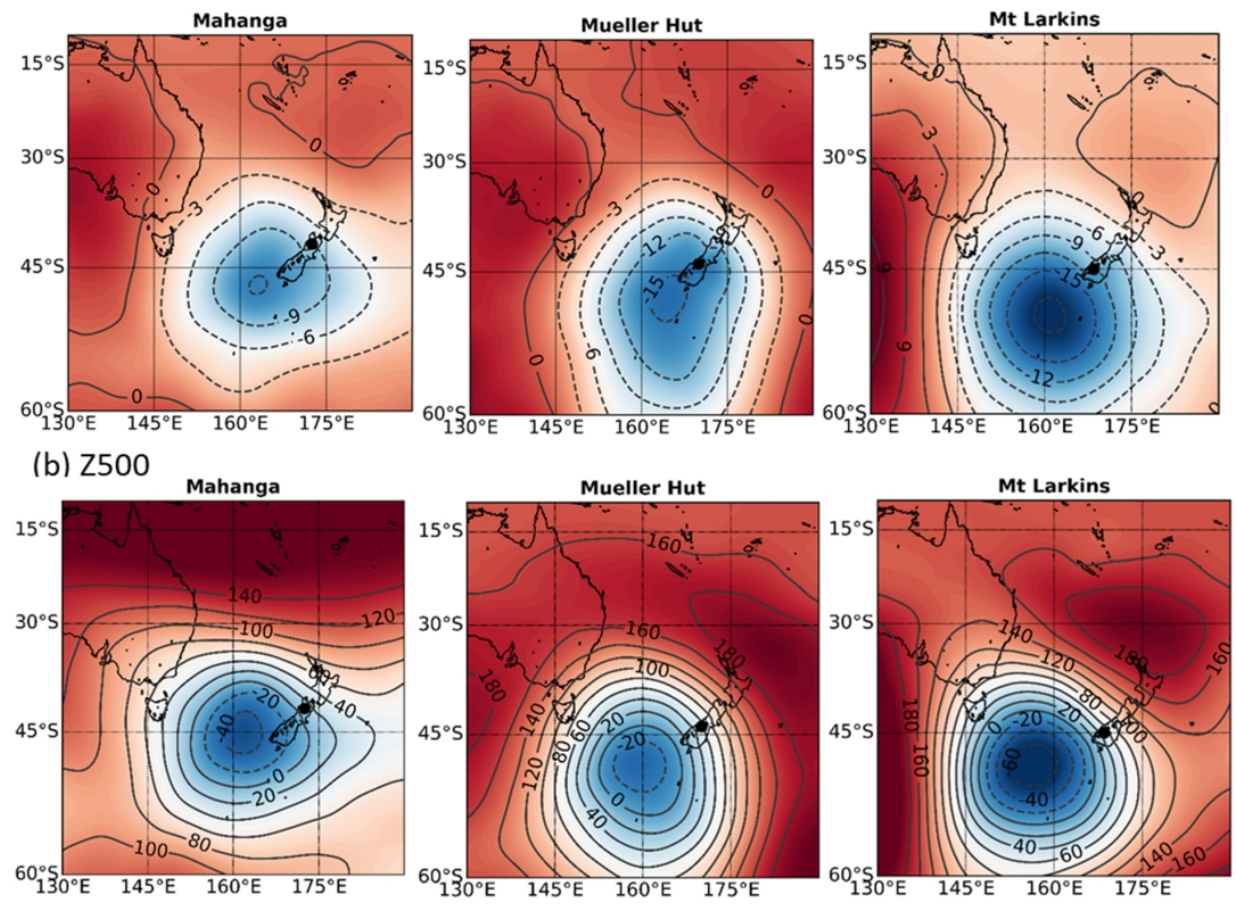

Figure 6. (a) Anomalies of SLP (hPa, contour intervals: $3 \mathrm{hPa}$ ) during the days of large snowfall. Solid lines indicate positive anomaly and dashed lines indicate negative anomalies. (b) Anomalies of Z500 (meters, contour intervals: 20 meters) during the days of large snowfall. The dashed lines show negative values.

$169 \times 132 \mathrm{~mm}(300 \times 300 \mathrm{DPI})$ 

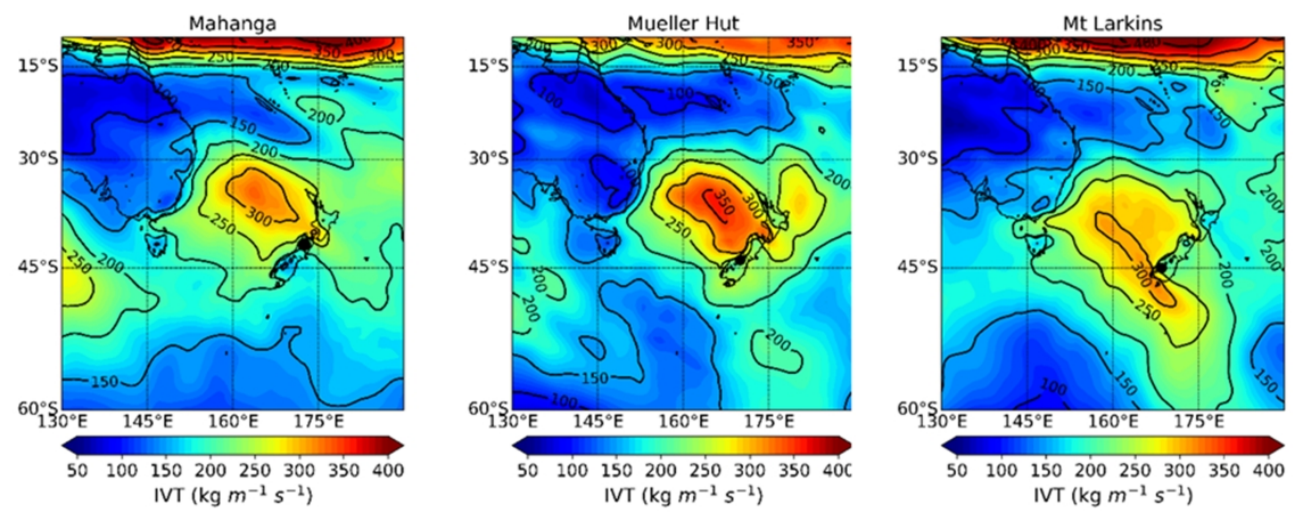

Figure 7. Average integrated vapour transport (IVT) during large snowfall events over Tasman Sea and the New Zealand region.

$314 \times 125 \mathrm{~mm}(300 \times 300$ DPI $)$

This article is protected by copyright. All rights reserved. 

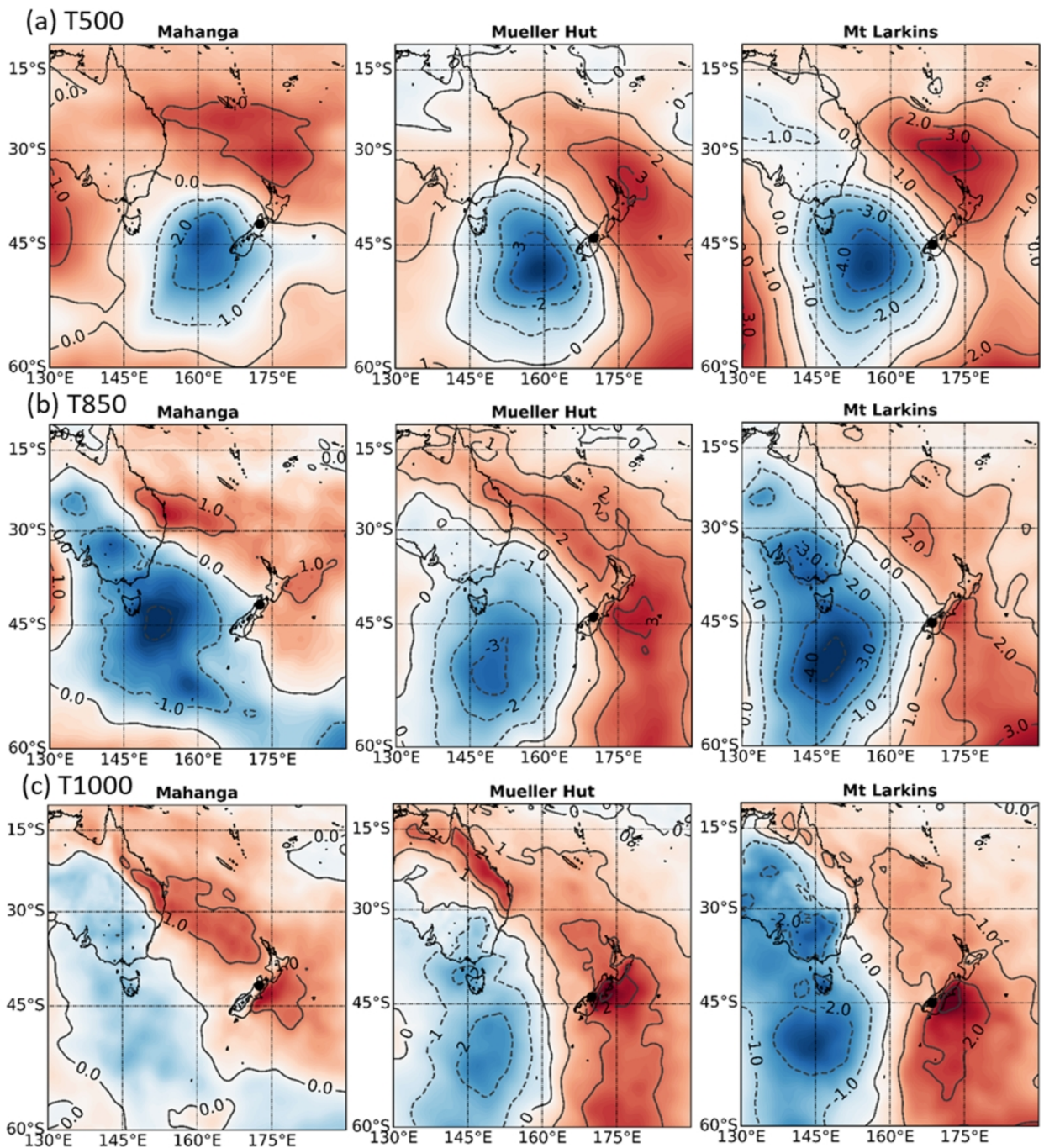

Figure 8. Anomalies of temperature $\left({ }^{\circ} \mathrm{C}\right.$, contour intervals: $\left.1{ }^{\circ} \mathrm{C}\right)$ during the days of large snowfall (a) at 500 $\mathrm{hPa}$, (b) $850 \mathrm{hP}$, and (c) $1000 \mathrm{hPa}$. The dashed lines show negative values.

$167 \times 180 \mathrm{~mm}(300 \times 300 \mathrm{DPI})$ 
(a) SLP


(b) $Z 500$



Figure 9. (a) One-day difference maps of SLP (hPa, contour intervals: $2 \mathrm{hPa}$ ) between the day of the snowfall events and the day prior to the snowfall events, and (b) difference maps of Z500 (meters, contour intervals: $2 \mathrm{~m}$ ) between the day of the snowfall events and the day prior to the snowfall events. The dashed lines show negative values.

$177 \times 136 \mathrm{~mm}(300 \times 300 \mathrm{DPI})$

This article is protected by copyright. All rights reserved. 

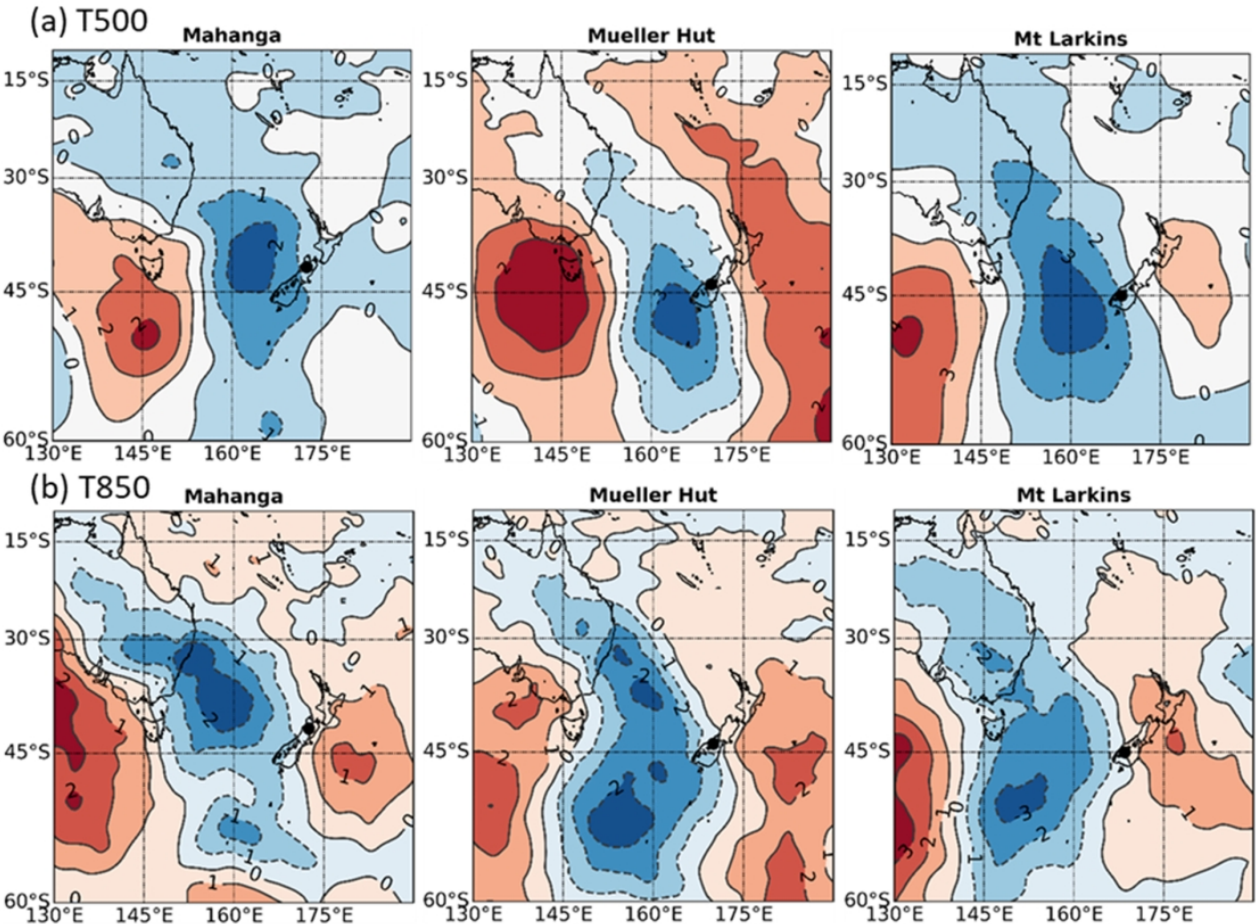

(c) T1000 Mahanga
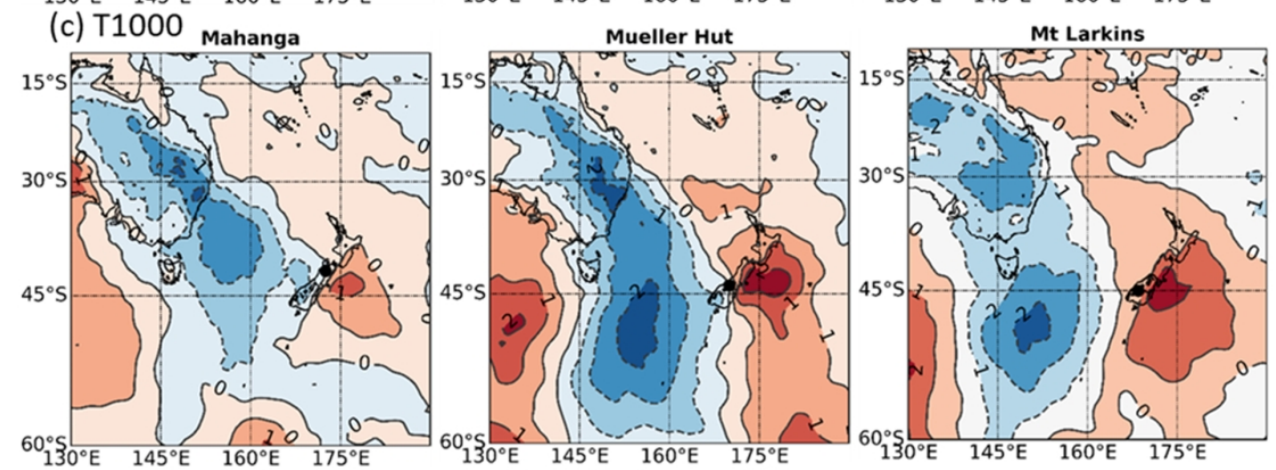

Figure 10. (a) Difference maps of T500 $\left({ }^{\circ} \mathrm{C}\right)$ between the day of the snowfall and the day prior, (b) difference maps of $\mathrm{T} 850\left({ }^{\circ} \mathrm{C}\right)$ between the day of the snowfall and the day prior, and (c) difference maps of $\mathrm{T} 1000\left({ }^{\circ} \mathrm{C}\right)$ between the day of the snowfall and the day prior. The dashed lines show negative values.

$166 \times 180 \mathrm{~mm}(300 \times 300 \mathrm{DPI})$ 


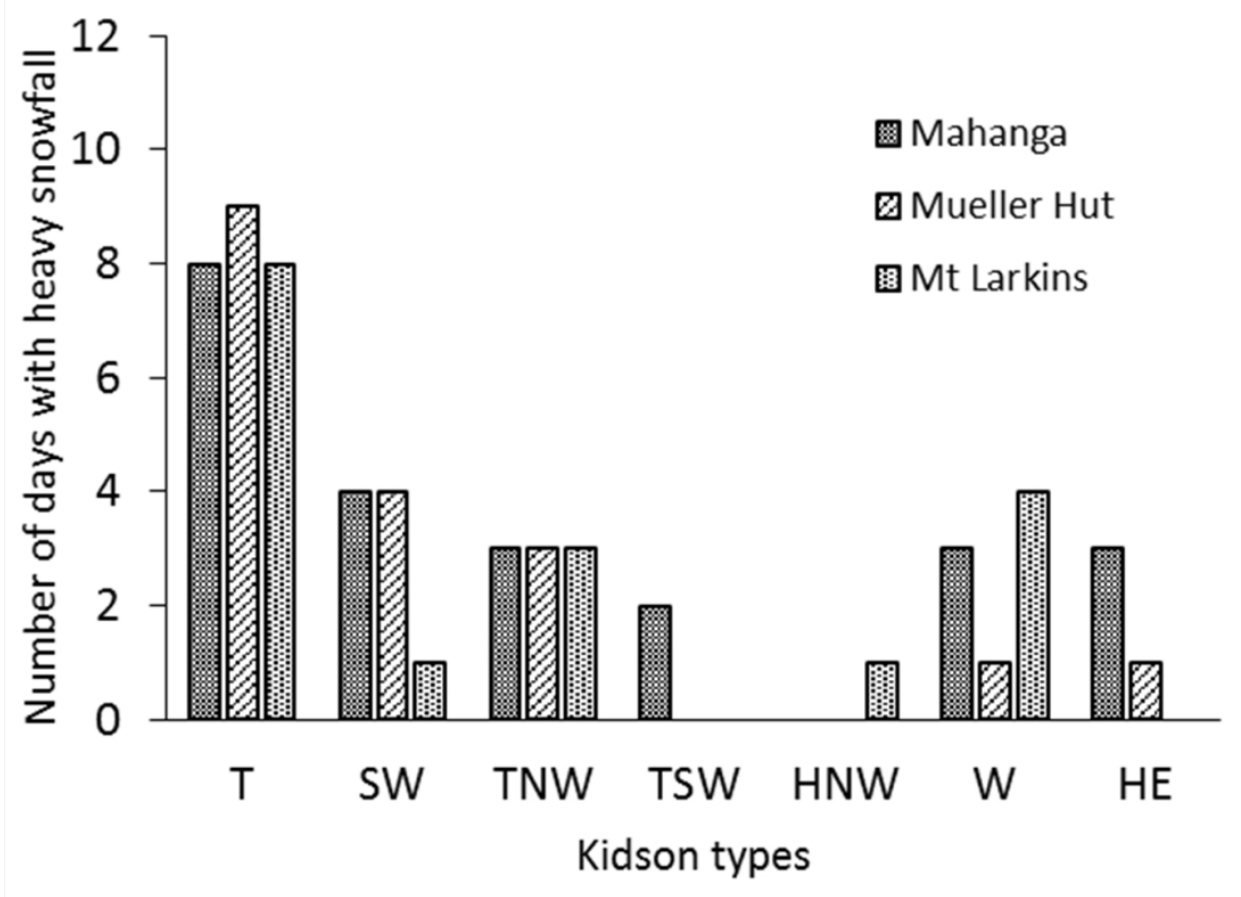

Figure 11 . The frequency of Kidson types during large snowfall events at three sites. $119 \times 88 \mathrm{~mm}(300 \times 300$ DPI $)$ 

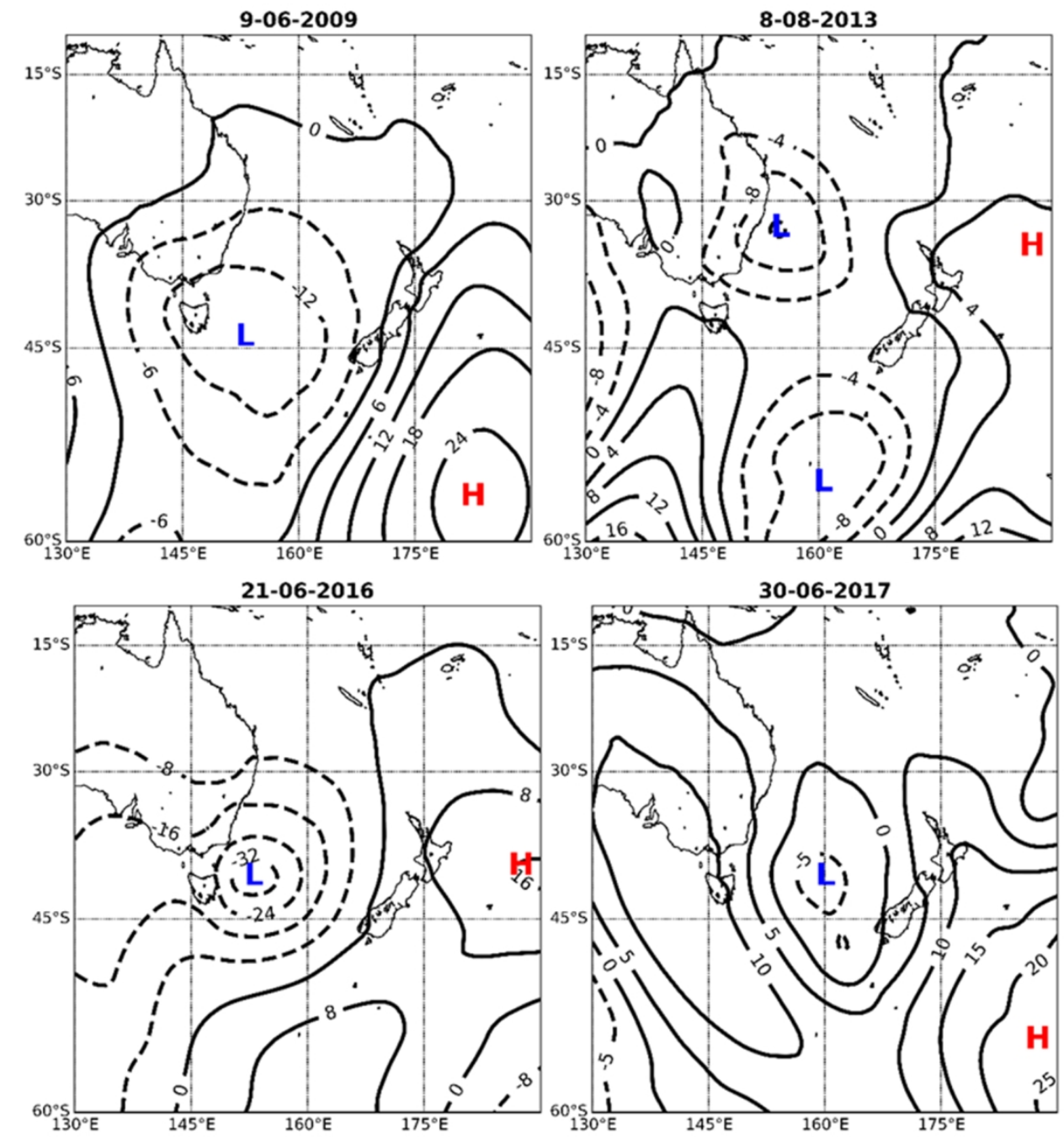

Figure 12. MSLP anomaly maps of snow events during the days with blocking regime (HE Kidson type) showing low pressure system west of the South Island and high pressure system on the east; blocking systems slow down the low pressure system and result in snow fall events on the western side of blocking anticyclones.

$140 \times 152 \mathrm{~mm}(300 \times 300 \mathrm{DPI})$

This article is protected by copyright. All rights reserved. 
Table 1. A summary of snowfall events at the three SIN sites investigated in this study

\begin{tabular}{|c|c|c|c|c|c|c|}
\hline Location & $\begin{array}{c}\text { Number } \\
\text { of } \\
\text { snowfall } \\
\text { days }\end{array}$ & $\begin{array}{c}\text { Average } \\
\text { annual snow } \\
\text { accumulation } \\
\text { (cm) }\end{array}$ & $\begin{array}{c}\text { Range of } \\
\text { maximum snow } \\
\text { depth }(\mathrm{cm})\end{array}$ & $\begin{array}{l}\text { Threshold of large } \\
\text { Snowfall events } \\
\text { (cm) (greater than } \\
90^{\text {th }} \text { percentile } \\
\text { value) }\end{array}$ & $\begin{array}{c}\text { Number } \\
\text { of large } \\
\text { snowfall } \\
\text { evets }\end{array}$ & $\begin{array}{c}\text { Average } \\
\text { contribution } \\
\text { of large } \\
\text { snowfall } \\
\text { events to } \\
\text { annual } \\
\text { accumulation } \\
\text { (\%) }\end{array}$ \\
\hline Mahanga & 195 & 241 & $\begin{array}{c}56(2013 / 14)- \\
125.4(2017 / 18)\end{array}$ & 12.5 & 23 & 22 \\
\hline $\begin{array}{c}\text { Mueller } \\
\text { Hut }\end{array}$ & 310 & 632.7 & $\begin{array}{l}212.4(2016 / 17)- \\
364.2(2012 / 13)\end{array}$ & 31 & 18 & 32 \\
\hline $\begin{array}{c}\text { Mt } \\
\text { Larkins }\end{array}$ & 114 & 395.9 & $\begin{array}{c}79(2014 / 15)- \\
147.5(2017 / 18)\end{array}$ & 18 & 17 & 25 \\
\hline
\end{tabular}

This article is protected by copyright. All rights reserved. 
Table 2. The frequency of synoptic regimes and Kidson types during large snowfall events

\begin{tabular}{|c|c|c|c|c|c|}
\hline \multicolumn{6}{|c|}{ Frequency of large snowfall events (\%) } \\
\hline $\begin{array}{l}\text { Synoptic } \\
\text { Regime }\end{array}$ & Kidson types & Mahanga & Mueller Hut & Mt Larkins & \% Total \\
\hline \multirow{4}{*}{ Troughing } & $\mathrm{T}$ & 34.8 & 66.6 & 58.8 & \multirow{5}{*}{77.8} \\
\hline & SW & 17.4 & 22.2 & 5.8 & \\
\hline & TNW & 13 & - & 5.8 & \\
\hline & TSW & 8.7 & - & - & \\
\hline \% Total & & 74 & 88.8 & 70.5 & \\
\hline \multirow{2}{*}{ Zonal } & HNW & - & 5.5 & 11.8 & \multirow{3}{*}{16} \\
\hline & W & 13 & - & 17.6 & \\
\hline \% Total & & 13 & 5.5 & 29.4 & \\
\hline Blocking & $\mathrm{HE}$ & 13 & 5.5 & - & \multirow{2}{*}{16.2} \\
\hline Total & & 13 & 5.5 & _ & \\
\hline
\end{tabular}

This article is protected by copyright. All rights reserved. 